\title{
Neuropeptide Y Depresses GABA-Mediated Calcium Transients in Developing Suprachiasmatic Nucleus Neurons: A Novel Form of Calcium Long-Term Depression
}

\author{
Karl Obrietan ${ }^{1}$ and Anthony N. van den Pol ${ }^{1,2}$ \\ ${ }^{1}$ Department of Biological Science, Stanford University, Stanford, California 94305, and 2 Section of Neurosurgery, Yale \\ University, School of Medicine, New Haven, Connecticut 06520
}

In contrast to its inhibitory role in mature neurons, GABA can exert excitatory actions in developing neurons, including mediation of increases in cytosolic $\mathrm{Ca}^{2+}$. Modulation of this excitatory activity has not been studied previously. We used $\mathrm{Ca}^{2+}$ digital imaging with Fura-2 to test the hypothesis that neuropeptide $Y$ (NPY) would depress GABA-mediated $\mathrm{Ca}^{2+}$ rises in neurons cultured from the developing suprachiasmatic nucleus (SCN). SCN neurons were chosen as a model system for this study because SCN neurons are primarily GABAergic, they express high levels of NPY and GABA receptors, and functionally, NPY causes profound phase-shifts in SCN-generated circadian rhythms.

Vigorous $\mathrm{GABA}$-mediated $\mathrm{Ca}^{2+}$ activity was found in young SCN neurons that were maintained in vitro for 4-14 d. NPY showed a dose-dependent rapid depression of the amplitude of $\mathrm{Ca}^{2+}$ rises generated by $\mathrm{GABA}$ released from presynaptic SCN axons. NPY exerted a long-term depression of cytosolic $\mathrm{Ca}^{2+}$ in the majority of neurons tested, which lasted more than $1 \mathrm{hr}$ after NPY washout. The magnitude of the NPY depression was dose-dependent. NPY did not affect $\mathrm{Ca}^{2+}$ levels when $\mathrm{GABA}_{\mathrm{A}}$ receptor activity was blocked by bicuculline; however, when bicuculline and NPY were withdrawn from the perfusion solution, the subsequent $\mathrm{Ca}^{2+}$ rise was either significantly reduced or completely absent, suggesting that the NPY receptor was activated in the absence of elevated intracellular $\mathrm{Ca}^{2+}$ and $\mathrm{GABA}_{\mathrm{A}}$ receptor activity, and that the latent effect of NPY was revealed only after depolarizing GABA stimulation was renewed. Pretreating neurons with pertussis toxin greatly reduced the ability of NPY to depress GABAergic $\mathrm{Ca}^{2+}$ rises, suggesting that the NPY modulation of the GABA activity was based largely on a mechanism involving pertussis toxinsensitive $G_{i} / G_{0}$ proteins.

NPY receptor stimulation depressed $(<30 \%)$ postsynaptic $\mathrm{Ca}^{2+}$ rises evoked by GABA $(20 \mu \mathrm{M})$ application in the presence of tetrodotoxin (TTX). The effects of NPY were mimicked by the NPY Y1 receptor agonist $\left[\mathrm{Pro}^{34}, \mathrm{Leu}^{31}\right]$ NPY and the Y2 receptor agonist NPY 13-36 and by peptide YY (PYY). Together, our data suggest that the $Y 1$ and $Y 2$ type NPY receptors act both presynaptically and postsynaptically to depress GABAmediated $\mathrm{Ca}^{2+}$ rises. If related mechanisms exist in peptide modulation of inhibitory GABA activity in mature neurons, this could underlie long-term changes in the behavior of neurons of the SCN necessary for phase-shifting the circadian clock by NPY. NPY also modulated GABA responses in neuroendocrine neurons from the hypothalamic arcuate nucleus. NPY thus can play an important role in evoking long-term depression of GABA-mediated $\mathrm{Ca}^{2+}$ activity in these developing neurons, allowing NPY-secreting cells to modulate the effects of GABA on neurite outgrowth, gene expression, and physiological stimulation. This is the first example of such a cellular memory: that is, long-term $\mathrm{Ca}^{2+}$ depression based on modulation of depolarizing GABA activity.

Key words: NPY; GABA receptor; suprachiasmatic nucleus; arcuate nucleus; calcium; neuroendocrine; modulation
A number of studies have shown that GABA acts as an excitatory transmitter during neuronal development, depolarizing the membrane potential and eliciting a cytosolic $\mathrm{Ca}^{2+}$ increase (Yuste and Katz, 1991; Horvath et al., 1993; Yamashita and Fukuda, 1993). The probable mechanism through which GABA elicits cytosolic $\mathrm{Ca}^{2+}$ increases in hypothalamic neurons seems to involve activation of the $\mathrm{GABA}_{\mathrm{A}}$ receptor; subsequent $\mathrm{Cl}^{-}$efflux attributable to a developmental depolarized $\mathrm{Cl}^{-}$reversal potential causes membrane depolarization and $\mathrm{Ca}^{2+}$ entry via voltage-activated $\mathrm{Ca}^{2+}$ channels (Obrietan and van den Pol, 1995; Chen et al, 1996).

\footnotetext{
Received Oct. 24, 1995; revised Feb. 29, 1996; accepted March 4, 1996.

This research was supported by National Institutes of Health Grants NS16296, NS10174, and NS34887, the National Science Foundation, and Air Force Office of Scientific Research. We thank Dr. H. C. Heller for encouragement and L. Haak for suggestions on earlier versions of the manuscript.

Correspondence should be addressed to Anthony N. van den Pol, Section of Neurosurgery, Yale University, School of Medicine, 333 Cedar Street, New Haven, CT 06520 .

Copyright (C) 1996 Society for Neuroscience $0270-6474 / 96 / 163521-13 \$ 05.00 / 0$
}

GABA modulation of cytosolic $\mathrm{Ca}^{2+}$ could affect various events during neuronal development. $\mathrm{Ca}^{2+}$ alters the rate and direction of neurite growth (Mattson and Kater, 1987) and influences gene expression (Vaccarino et al., 1992; Bading et al., 1993). Similarly, GABA increases neurite outgrowth of brain and retinal neurites (Spoerri, 1988; Michler, 1990; Barbin et al., 1993) and modulates synapse formation in cultured cells (Meier et al., 1984; Hansen et al., 1987). Later in development, GABA reverses roles and assumes its classic function as an inhibitory neurotransmitter, suppressing membrane depolarizing excitatory activity. A previously unstudied question that we address is whether the $\mathrm{Ca}^{2+}$-elevating ability of GABA can be modulated during development by peptides such as neuropeptide Y (NPY).

NPY is a 36 amino acid peptide that is found throughout the central and peripheral nervous system from the time of neurogenesis to adulthood (Allen et al., 1984; Chronwall et al., 1985; Woodhams et al., 1985; Barnea et al., 1991). Its neuromodulatory role is widespread and complex. At the cellular level, NPY has 
been reported to act either presynaptically (via the NPY Y2 receptor) or postsynaptically (via the NPY Y1 receptor) to regulate neuronal excitability (Khanna et al., 1993; Simonneaux et al., 1994). Modulation of $\mathrm{Ca}^{2+}$ influx through voltage-activated $\mathrm{Ca}^{2+}$ channels may be one mechanism through which NPY regulates neural activity (Walker et al., 1988; Wiley et al., 1990, 1993; McQuiston et al., 1996). Many physiological and behavioral effects of NPY also have been identified. For example, the infusion of NPY into the hypothalamus modulates circulating levels of the pituitary hormone corticosterone (Albers et al., 1990), stimulates bouts of feeding that can last several hours (Stanley and Leibowitz, 1985), and alters body temperature (Jolicoeur et al., 1995).

A brain region well suited for the study of NPY modulation of GABA-mediated activity is the suprachiasmatic nucleus (SCN) of the hypothalamus. The SCN has a large number of presynaptic GABAergic axons, and most neurons in the SCN synthesize GABA (Card and Moore, 1984; van den Pol and Tsujimoto, 1985; Decavel and van den Pol, 1990; Morely and Flood, 1990; Moore and Speh, 1993). Frequent synaptic contacts between peptidergic and GABAergic cells are found in the SCN (van den Pol and Gorcs, 1986). The SCN functions as the circadian pacemaker of the brain (for review, see van den Pol and Dudek, 1993). This circadian rhythm is in turn entrained to the environmental light cycle via photic input from the optic nerve. In addition to this direct photic pathway, NPY- and GABA-containing afferents of neurons from the intergeniculate leaflet (IGL) form an indirect pathway by which photic information is transmitted to the SCN (Swanson et al., 1974; Card and Moore, 1989; Botchkina and Morin, 1995). Damage to, or electrical stimulation of, NPYcontaining neurons of the IGL results in a phase-shift of the circadian rhythm (Harrington et al., 1985; Harrington and Rusak, 1986; Johnson et al., 1989; Rusak et al., 1989). Behavioral and brain-slice studies have shown that NPY applied to the SCN can phase-shift circadian rhythms by 1 hr or more (Albers and Ferris, 1984; Medanic and Gillette, 1993; Shibata and Moore, 1993; Huhman and Albers, 1994) and that the effects of NPY can be inhibited by the GABA $\mathrm{A}_{\mathrm{A}}$ receptor antagonist bicuculline (Huhman et al., 1995). Because extensive phase shifts in the circadian rhythm can be generated by brief exposure to light or by a single exposure to NPY, a long-duration change in cellular behavior would be expected. The mechanisms used by NPY to exert a long-lasting effect on neuronal activity have not been examined.

The studies presented here suggest that NPY not only can modulate the excitatory actions of GABA in developing neurons but also can cause a long-term depression of $\mathrm{GABA}$-elicited $\mathrm{Ca}^{2+}$ activity, a form of cellular learning, mediated through $\mathrm{Y} 1$ and $\mathrm{Y} 2$ reccptors with both pre- and postsynaptic components.

\section{MATERIALS AND METHODS}

Tissue culture. Two techniques were used to dissect the SCN from embryonic day 19-21 (E19-21) Sprague-Dawley rats. In the first technique, the SCN was dissected from whole brains using anatomical markers to identify its location. The SCN was identified by its position at the ventral surface of the hypothalamus, extending laterally from the third ventricle and dircetly above the optic chiasm. Tissuc was washed immediately three times in standard tissue culture medium (glutamate- and glutamine-free minimal essential medium, $10 \%$ fetal bovine serum, 100 $\mathrm{U} / \mathrm{ml}$ penicillin/streptomycin, and $6 \mathrm{gm} / \mathrm{l}$ glucose) and then incubated in a papain digestion solution (Earle's balanced salt solution containing 10 units $/ \mathrm{ml}$ papain, $500 \mu \mathrm{M}$ EDTA, $1.5 \mu \mathrm{M} \mathrm{CaCl}_{2}, 0.2 \mathrm{mg} / \mathrm{ml}$ L-cysteine) for $30 \mathrm{~min}$. The papain solution was removed by aspiration after the tissue was pelleted by centrifugation. The tissue was then triturated into a single-cell suspension and plated onto poly-D-lysine-coated glass coverslips $(22 \times 22 \mathrm{~mm})$. The protocol for the coverslip preparation included washing with mild detergent, rinsing three times with distilled water, and then autoclaving. High local neuronal density was ensured by plating the cells within a $7 \mathrm{~mm}$ diameter glass ring placed on the coverslip. The glass ring was removed $60 \mathrm{~min}$ after plating. Cultures were maintained in standard tissue culture medium at $37^{\circ} \mathrm{C}$ and $5 \% \mathrm{CO}_{2}$ in a Napco 6100 incubator. The arcuate nucleus, situated at the ventral surface of the hypothalamus, caudal to the SCN, and on either side of the third ventricle was cultured in a manner identical to that described above for the SCN. Cytosine arabinofuranoside $(1 \mu \mathrm{M})$ was added to the tissue culture medium of cultures maintained over $6 \mathrm{~d}$ to reduce astrocyte proliferation.

Because the first dissection method likely included cells from areas outside the SCN, we used a second technique in which the SCN was microdissected precisely. Whole neonatal brain was chilled to $4{ }^{\circ} \mathrm{C}$ and then cut into $400-500 \mu \mathrm{m}$ coronal slices using a tissue chopper. The slice containing the SCN was identified by morphological markers. A polished 22 gauge needle was used to punch out the SCN. Punched SCN tissue was placed briefly in the papain digestion solution described above to help wash off cellular debris and then was placed on poly-D-lysine-coated glass coverslips. No trituration was performed, thereby allowing SCN neurons to be cultured as an intact organotypic block with general neuroanatomical features and local connections intact. Cultures were maintained as described above.

Calcium digital imaging. Coverslips initially were incubated in standard HEPES perfusion solution (10 HEPES, $137 \mathrm{~mm} \mathrm{NaCl}, 25 \mathrm{~mm}$ glucose, 5 $\mathrm{mm} \mathrm{KCl}, 1 \mathrm{~mm} \mathrm{MgCl}, 3 \mathrm{~mm} \mathrm{CaCl}_{2}, \mathrm{pH}$ 7.4) containing $5 \mu \mathrm{M}$ Fura-2 acetoxymethyl ester for $30 \mathrm{~min}$ at $37^{\circ} \mathrm{C}$. Neurons were then washed three times and allowed to recover for $15 \mathrm{~min}$ before the start of the experiment. Coverslips were placed in a laminar flow perfusion chamber (Forscher et al., 1987). Rapid changes in the content of the perfusion solution were accomplished by placing an individual port for each perfusion solution at the laminar glass interface. Solution passed through the $180 \mu \mathrm{l}$ perfusion chamber as a straight wave, thereby minimizing mixing of different perfusion solutions. Complete washout of the chamber was achieved in $\sim 5 \mathrm{sec}$. This rapid and complete washout is one great advantage of using monolayer cultured cells for studying long-term or latent effects of neuroactive compounds.

Cells were imaged on a Nikon Diaphot 300 inverted microscope with an Olympus DApo $40 \times$ objective with high UV light transmittance. $\mathrm{Ca}^{2+}$ responses were recorded from the neuronal soma. Neurons were identified by their phase-bright appearance. Occasionally, NMDA also was used to verify the identity of neurons. Only healthy neurons responded to NMDA; astrocytes did not. All experiments were performed at room temperature.

A Suttcr filtcr whecl controlled by a Lambda 10 microprocessor was used to switch the excitation light from a $150 \mathrm{~W}$ xenon lamp between 340 and $380 \mathrm{~nm}$. Light emitted from the neurons was passed back through the microscope, a $480 \mathrm{~nm}$ filter, and then focused on a Hamamatsu 2400 silicon intensified target video camera. Excitation light was attenuated $90 \%$ to inhibit photobleaching and phototoxicity, thereby allow recording sessions of $>90 \mathrm{~min}$. Data from up to 64 neurons could be recorded simultaneously by a 486 PC computer with Fluor software (Universal Imaging, West Chester, PA). Sixteen viden frames $(500 \mathrm{msec})$ of data were recorded from both wavelengths every $2 \mathrm{sec}$. A shutter was used to block excitation light between the periods of data acquisition. Data were collected in the form of digitized, background-subtracted, single-cell ratiometric values. As described by Grynkiewicz et al. (1985), ratiometric fluorescent values were converted to free $\mathrm{Ca}^{2+}$ values with the equation $\left[\mathrm{Ca}^{2+}\right]_{\mathrm{i}}=K_{\mathrm{d}}\left(R-R_{\min }\right) /\left(R_{\max }-R\right)$, where $R$ is the ratio of the two fluorescence intensities, $R_{\min }$ is the ratio in the absence of $\mathrm{Ca}^{2+}$, and $R_{\max }$ is the ratio in a saturating concentration of $\mathrm{Ca}^{2+}$. The $K_{\mathrm{d}}$ for Fura $2+$ $\mathrm{Ca}^{2+}$ was taken to be $224 \mathrm{~nm}$ (Grynkiewicz et al., 1985). Calibrated $\mathrm{Ca}^{2+}$ data from single neurons were transferred to an Apple 840AV computer and analyzed with Igor Pro software (WaveMetrics).

For assays that measured the effect of NPY receptor agonists on endogenous GABA-mediated $\mathrm{Ca}^{2+}$ rises, we initially determined the average $\mathrm{Ca}^{2+}$ level in the presence of bicuculline for the $15 \mathrm{sec}$ immediately preceding the removal of bicuculline from the perfusion solution. The $\mathrm{Ca}^{2+}$ increase after bicuculline removal was determined by averaging the $\mathrm{Ca}^{2+}$ rise over the $15 \mathrm{sec}$ period immediately preceding the application of NPY receptor agonist. The mean $\mathrm{Ca}^{2+}$ change in the presence of NPY receptor agonist was determined by averaging the $\mathrm{Ca}^{2+}$ levels over a $15 \mathrm{sec}$ period $100 \mathrm{sec}$ after the application of NPY. Data from individual neurons were then pooled as a population mean. Responses are reported as the mean $\mathrm{Ca}^{2+}$ rise from basal $\mathrm{Ca}^{2+}$ level (in the presence of bicuculline) \pm SEM. For assays that measured peak exogenously evoked $\mathrm{Ca}^{2+}$ rises, the mean basal $\mathrm{Ca}^{2+}$ level over the $15 \mathrm{sec}$ immediately preceding 
the evoked $\mathrm{Ca}^{2+}$ rise was averaged. This value was subtracted from the peak-evoked $\mathrm{Ca}^{2+}$ level to determine the maximal evoked $\mathrm{Ca}^{2+}$ rise. Data from individual neurons were then pooled as a population mean. Responses are reported as the mean/peak $\mathrm{Ca}^{2+}$ rise from mean basal $\mathrm{Ca}^{2+}$ level \pm SEM. Experiments were performed on neurons after 3-5 d in vitro, unless stated otherwise.

Cytosine arabinofuranoside, GABA, muscimol, NMDA, benextramine, and poly-D-lysine were acquired from Sigma. D,L-2-Amino-5phosphonopentanoic acid (AP5), CNQX, baclofen, bicuculline, nimodipinc, and TTX wcrc acquired from Research Biochemicals International. NPY, NPY 13-36, $\left[\mathrm{Pro}^{34}, \mathrm{Leu}^{31}\right]$ NPY, and PYY were acquired from Peninsula Labs. Papain was acquired from Worthington Biochemicals (Freehold, NJ), DMEM from Gibco (Gaithersburg, MD), C2-NPY from Bachem California (Torrance, CA), and Fura-2 acetoxymethyl ester from Molecular Probes (Eugene, OR).

\section{RESULTS}

\section{Depression of neuronal $\mathrm{Ca}^{2+}$ by NPY}

As described previously (Obrietan and van den Pol, 1995), GABA secreted from neurons derived from the developing $\mathrm{SCN}$ induced sustained $\mathrm{Ca}^{2+}$ elevations in a majority of neurons. In the present study, the ability of NPY to modulate GABA-mediated $\mathrm{Ca}^{2+}$ increases was assayed using neurons derived from E19-E21 SCN after $4 \mathrm{~d}$ in vitro (DIV) (Fig. 1). To determine a baseline $\mathrm{Ca}^{2+}$ level, neurons were perfused initially with the $\mathrm{GABA}_{\mathrm{A}}$ receptor antagonist bicuculline $(20 \mu \mathrm{M})$. There was a rapid elevation in $\mathrm{Ca}^{2+}$ after bicuculline was removed from the perfusion solution.

Figure $1 A$ shows that the application of NPY (100 nM) to the perfusion solution caused a rapid and dramatic depression in the GABA-mediated $\mathrm{Ca}^{2+}$ level. In the presence of bicuculline, the resting $\mathrm{Ca}^{2+}$ level was $67 \pm 2 \mathrm{nM}$. After bicuculline was removed from the perfusion solution, the $\mathrm{Ca}^{2+}$ level increased to $124 \pm 3 \mathrm{~nm}$, a $56 \mathrm{nM} \mathrm{Ca}^{2+}$ rise. The application of NPY reduced the $\mathrm{Ca}^{2+}$ rise to $16 \pm 2 \mathrm{nM}$, representing a statistically significant $(p<0.001$, one-tailed $t$ test) $71 \%$ drop in the GABA-mediated $\mathrm{Ca}^{2+}$ level $(n=111)$. In some neurons, NPY was nearly as effective as bicuculline at depressing $\mathrm{Ca}^{2+}$ levels. 'I'he $\mathrm{Ca}^{2+}$ level of 59 of 111 neurons was depressed to within 10 nM of the bicuculline-defined baseline. These data are from five indepcndent experiments. Only one experiment was performed per coverslip. We compared the response of cells from each of five coverslips to determine whether there was a significant difference in means or variances. Using ANOVA tests, we found no difference either in the responses to bicuculline removal or in the NPY-mediated depression of $\mathrm{Ca}^{2+}$ rises between different coverslips.

Figure $1 C$ shows that the magnitude of the NPY-mediated depression of $\mathrm{GABAergic} \mathrm{Ca}^{2+}$ levels was dose-dependent, with statistically maximal effects exerted at $100 \mathrm{~nm}$. A much smaller effect was seen with 5 and $15 \mathrm{~nm}$ NPY. Neurons not stimulated with NPY exhibited extended and stable $\mathrm{Ca}^{2+}$ rises from baseline on bicuculline removal (Fig. $1 D$ ).

A very interesting finding was that NPY exerted a long-term $\mathrm{Ca}^{2+}$ depression that lasted well after NPY was removed from the perfusion solution. The neuron shown in Figure $1 A 1$ is an example of this extended effect; $\mathrm{Ca}^{2+}$ was depressed to near baseline levels and remained depressed after the removal of NPY. As a measure of the long-term effectiveness of NPY, we found that $>68 \%$ of $\mathrm{SCN}$ neurons did not recover at least $50 \%$ of their pre-NPY $\mathrm{Ca}^{2+}$ level by $6 \mathrm{~min}$ after a $2 \mathrm{~min}$ NPY application $(n=115)$. In the absence of NPY receptor stimulation, no neuron had a GABAmediated $\mathrm{Ca}^{2+}$ rise decrease by $50 \%$ over a $6 \min$ period $(n=25)$.

We assayed the efficacy of NPY (100 nM) after 11 DIV to determine whether its effects on GABA-mediated $\mathrm{Ca}^{2+}$ persisted during later periods of neuronal development (Fig. $1 B$ ). As with 4 DIV neurons, NPY was a potent inhibitor of GABAergic $\mathrm{Ca}^{2+}$ rises after $11 \mathrm{DIV}$. Long-term $\mathrm{Ca}^{2+}$ depression was not associated with small pre-NPY $\mathrm{Ca}^{2+}$ rises. NPY induced long-term $\mathrm{Ca}^{2+}$ depression in neurons with a relatively large $\mathrm{Ca}^{2+}$ rise (Fig. 1B1), whereas the NPY-mediated $\mathrm{Ca}^{2+}$ depression in a neuron with a relatively small $\mathrm{Ca}^{2+}$ rise (Fig. $1 B 2$ ) was rapidly reversible, recovering much more rapidly. For all endogenous activity assays, neurons were perfused constantly with the broad spectrum ionotropic glutamate receptor antagonists AP5 $(100 \mu \mathrm{M})$ and CNQX $(10 \mu \mathrm{M})$ to remove any complicating effects of glutamatemediated $\mathrm{Ca}^{2+}$ rises and NPY/glutamate interactions.

\section{NPY-mediated long-term $\mathrm{Ca}^{2+}$ depression}

To better assess NPY actions as a long-tcrm depressor of GABAmediated $\mathrm{Ca}^{2+}$ levels, SCN neurons were imaged for $>1$ hr after a single $2 \mathrm{~min}$ application of NPY. Figure $2 A$ shows four neurons that were recorded simultaneously. The removal of bicuculline initiated a large $\mathrm{Ca}^{2+}$ increase in all neurons. The application of NPY (100 nM) to the perfusion solution drastically reduced the $\mathrm{Ca}^{2+}$ levels in all neurons. Neurons showed two general responses to the removal of NPY. The first group (Fig. $2 A 1-A 2$ ) did not recover to pre-NPY $\mathrm{Ca}^{2+}$ levels even after $60 \mathrm{~min}$. Although NPY conferred a long-term reduction in the $\mathrm{Ca}^{2+}$ level, these neurons were still synaptically active; $\mathrm{Ca}^{2+}$ levels were elevated relative to levels in the presence of bicuculline, and intermittent periods of increased activity were visible. The second group (Fig. $2 A 3-A 4$ ) showed varied $\mathrm{Ca}^{2+}$ recovery rates after the removal of NPY. Of the 27 neurons recorded simultaneously for $40 \mathrm{~min}, 12$ neurons showed $>50 \%$ recovery, whereas 15 neurons showed $<50 \%$ recovery to pre-NPY Ca ${ }^{2+}$ lcvels. This experiment was repeated with neurons from three additional coverslips with similar results. Spontaneous $\mathrm{Ca}^{2+}$ depression and recovery of the type seen with the addition and washout of NPY was never observed.

Additional experiments were performed to explore the mechanism by which NPY triggers long-term $\mathrm{Ca}^{2+}$ depression. Specifically, because NPY may bind nonspecifically to membranes (McLean et al., 1990), NPY may exert long-term effects by remaining cell-associated and rebinding to the NPY receptor, thereby affecting $\mathrm{Ca}^{2+}$ levels for extended periods after presumptive NPY washout. To reduce this possibility, we used the truncated NPY analog C2-NPY that lacks structural elements involved in nonspecific binding (McLean et al., 1990). Therefore, C2-NPY should rapidly wash out of the perfusion solution. Data were collected and pooled from three different coverslips. Figure $2 B$ shows that the addition of C2-NPY $(100 \mu \mathrm{M})$ to the perfusion solution caused a rapid depression of the GABAcrgic $\mathrm{Ca}^{2+}$ rise. The $\mathrm{Ca}^{2+}$ rise immediately before C2-NPY application was $57 \pm$ $5 \mathrm{nM}$; C2-NPY administration decreased the $\mathrm{Ca}^{2+}$ rise to $27 \pm 2$ $\mathrm{nM}$, representing a $47 \%$ drop in $\mathrm{Ca}^{2+}$ levels $(n=37)$. The $\mathrm{Ca}^{2+}$ level was depressed after the withdrawal of C2-NPY and remained depressed for the duration of the experiment ( $>30 \mathrm{~min}$ ). C2-NPY triggered long-term $\mathrm{Ca}^{2+}$ depression in $37 \%$ of neurons $(n=37)$. The general appearance of the extended $\mathrm{Ca}^{2+}$ depression triggered by C2-NPY is virtually identical to the extended $\mathrm{Ca}^{2+}$ depression elicited by NPY (Fig. 2A1-A2). By 20 min after its addition, C2-NPY still depressed $\mathrm{Ca}^{2+}$ by $51 \%$; in comparison, NPY depressed $\mathrm{Ca}^{2+}$ by $43 \%$. These results are not consistent with the idea that the long-term effect is attributable to NPY stickiness. Our data suggest that NPY agonists act rapidly to initiate long-term depression.

To test further the possibility that the long-term effect may have 
A. 4 DIV
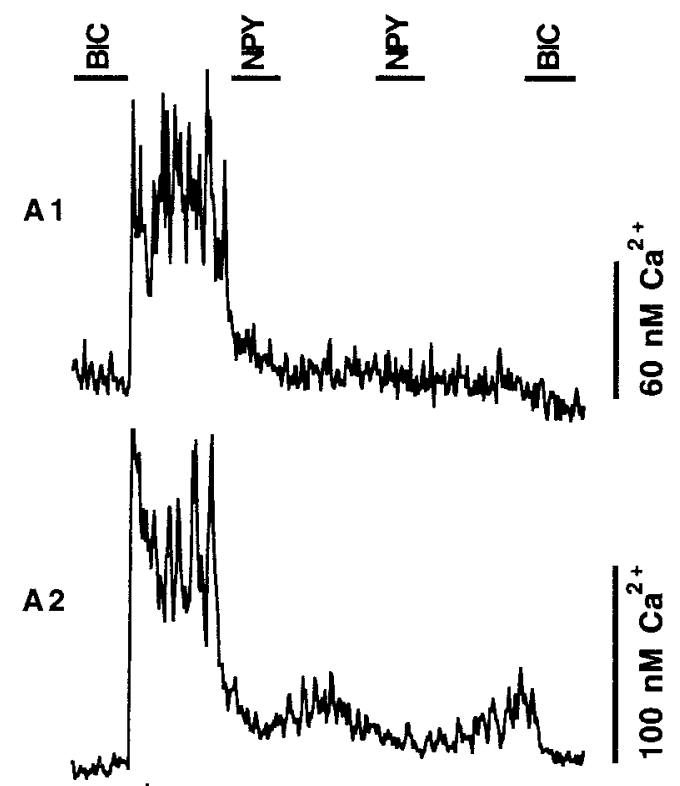

A3

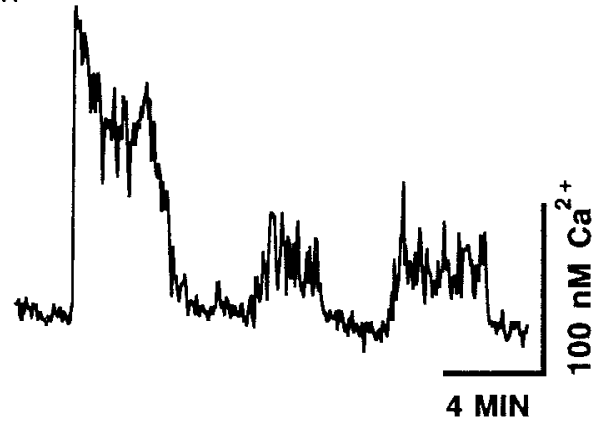

C. CONCENTRATION-DEPENDENT EFFECT

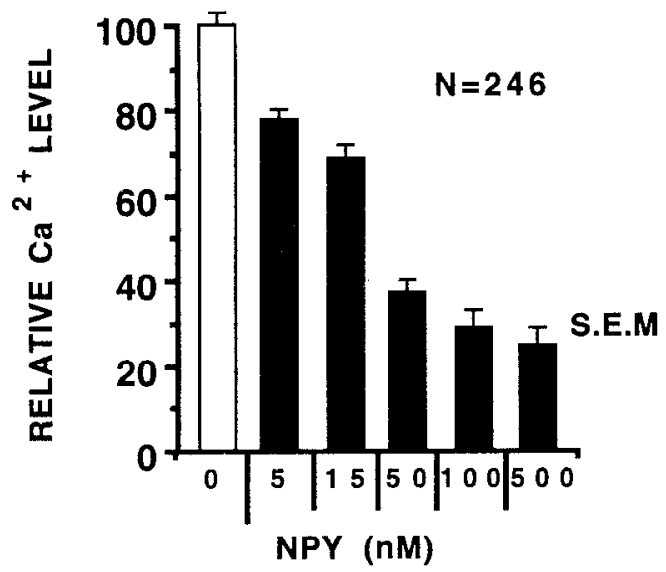

B. 11 DIV

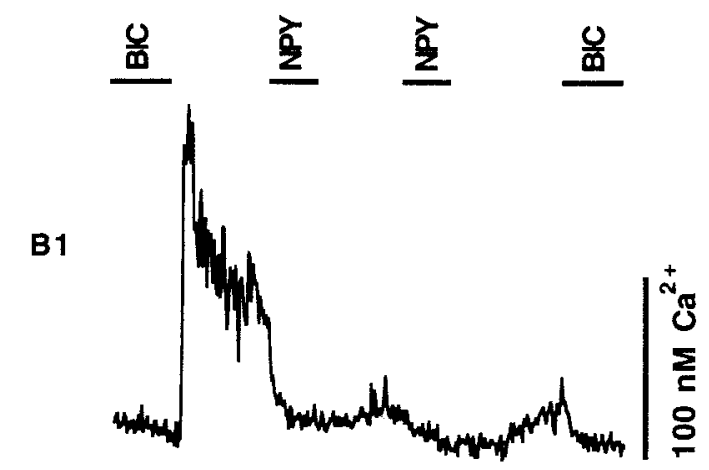

B2

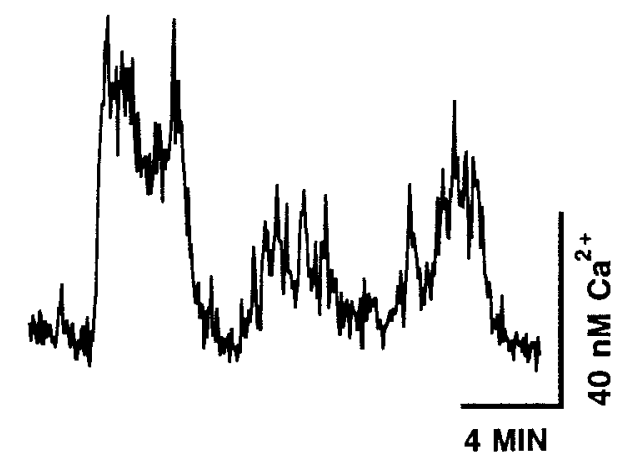

D. 4 DIV
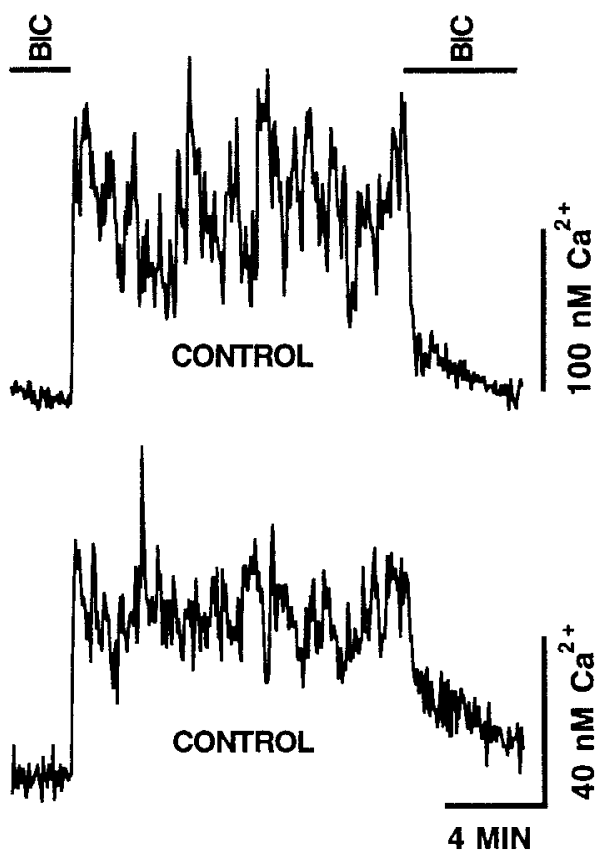

Figure 1. 1, The removal of the $\mathrm{GABA}_{\mathrm{A}}$ receptor antagonist bicuculline $(B I C)(20 \mu \mathrm{M})$ from the perfusion solution caused an immediate $\mathrm{Ca}^{2+}$ rise in neurons from the SCN cultured for $4 \mathrm{~d}$ in vitro $(D I V)$. The addition of $N P Y(100 \mathrm{nM})$ caused a rapid depression in the GABAergic Ca ${ }^{2+}$ rise. The ability of neurons to recover to pre-NPY $\mathrm{Ca}^{2+}$ levels differed significantly, with some showing a modest recovery $(A 2, A 3)$ and others not recovering $(A 1)$. $B$, The effects of NPY on endogenous, GABA-medialed, $\mathrm{Ca}^{2+}$ rises persisted with time in culture $(11 \mathrm{DN})$. $C$, The effect of NPY on GABA-mediated Ca?+ rises was concentrationdependent. The $\mathrm{Ca}^{2+}$ rise from a bicuculline-defined baseline was determined $15 \mathrm{sec}$ before and $100 \mathrm{sec}$ after the application of NPY. These values were normalized such that the $\mathrm{Ca}^{2+}$ rise just before the application of NPY (white bar) was set equal to 100\%. Error bars represent the SEM. $N$ refers to the total number of neurons assayed. The $\mathrm{Ca}^{2+}$ rise defined from a bicuculline $(20 \mu \mathrm{M})$ baseline was determined 15 sec before and 100 sec after the application of $\mathrm{NPY}$ receptor agonists (see Materials and Methods for a full description). $D$, Control experiments show that in the absence of NPY, the Ca ${ }^{2+}$ rise was maintained for an extended time. $\mathrm{Ca}^{2+}$ levels in the presence of bicuculline were usually between 45 and $80 \mathrm{nM}$. Vertical bars to the right of each neuron represent the calibrated $\mathrm{Ca}^{2+}$ level. Horizontal bars represent the time scale for a group of neurons. The ionotropic glutamate receptor antagonists AP5 and CNQX were present in all perfusion solutions to eliminate the potentially complicating interactions between NPY and glutamatergic neurons. 
MINIMAL RECOVERY

A1

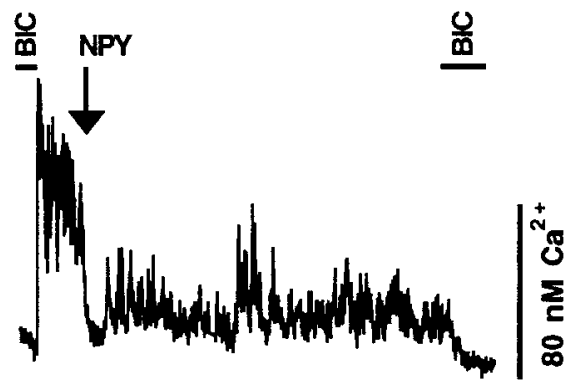

A2
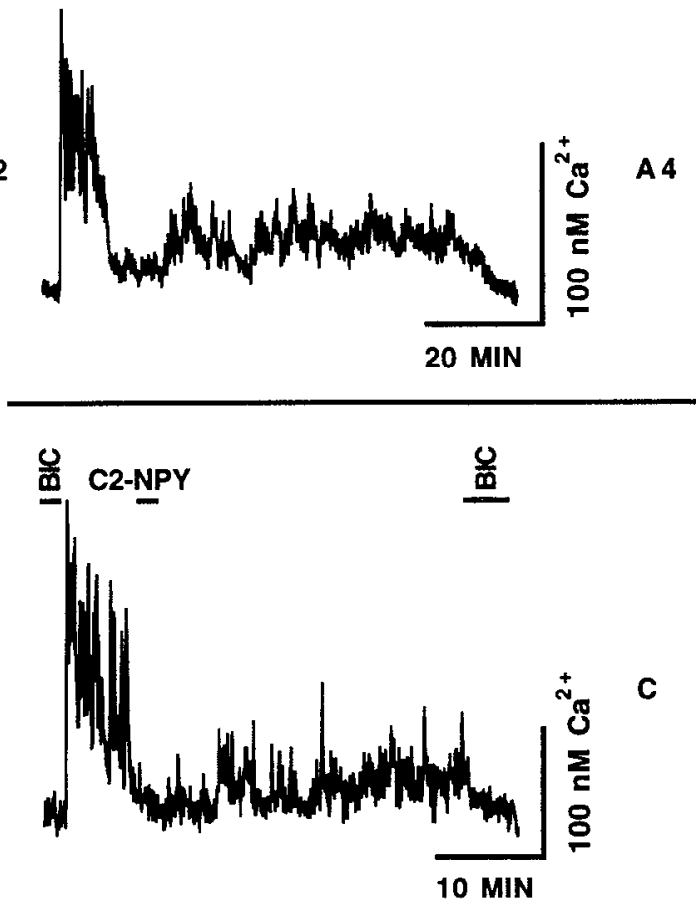

D1

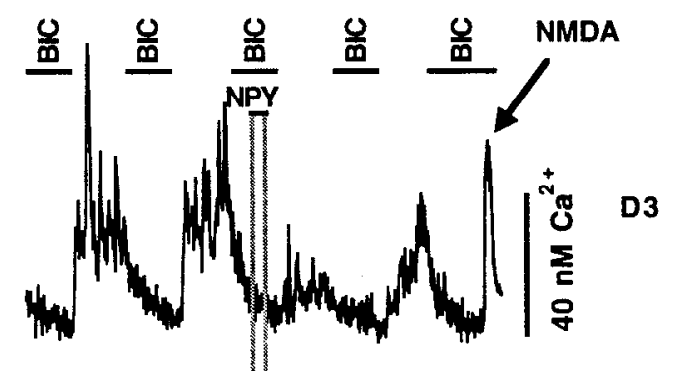

D2

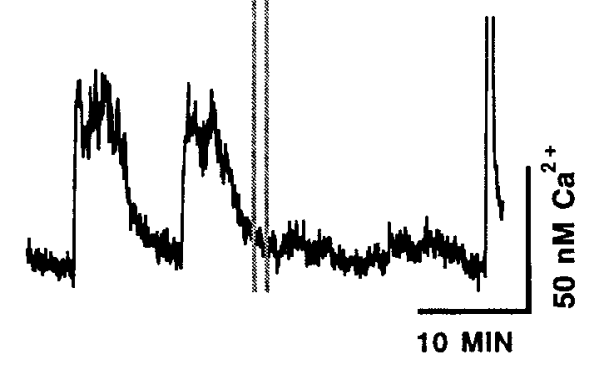

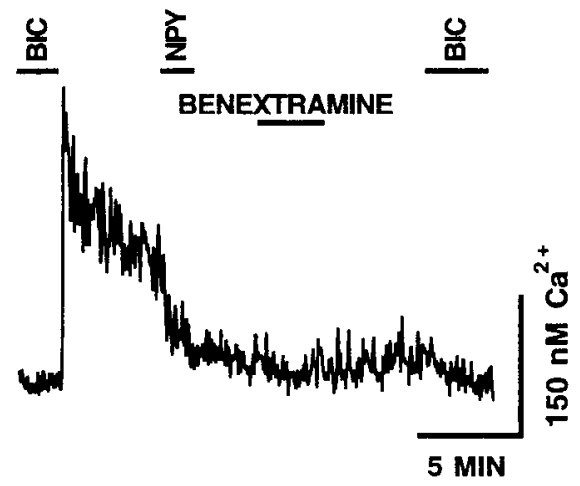

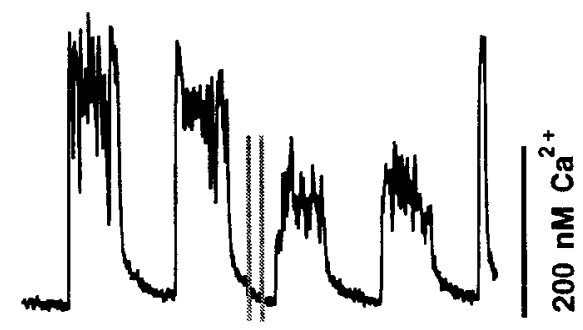

\section{RECOVERY}
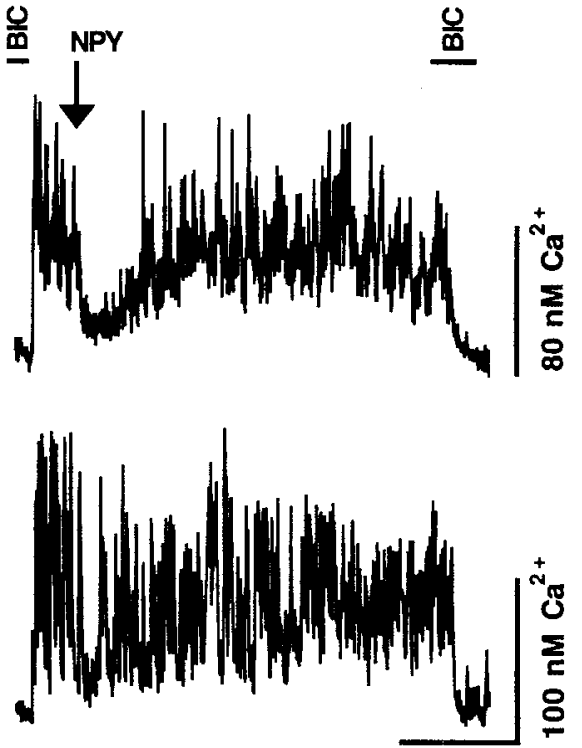

20 MIN

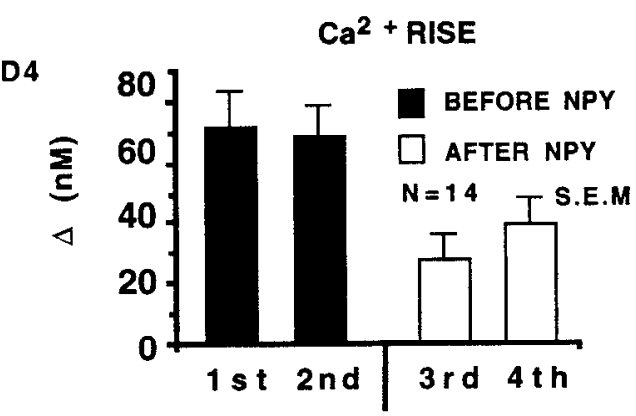

Figure 2. $A$, The ability of NPY to depress endogenous $\mathrm{G} \Lambda \mathrm{B} \Lambda$-mediated $\mathrm{Ca}^{2+}$ rises was assayed for $>60 \mathrm{~min}$. The $\mathrm{Ca}^{2+}$ rise initiated by the removal of bicuculline $(B I C)(20 \mu \mathrm{M})$ was depressed by a 2 min application of NPY (100 nM) (arrow). Representative SCN neurons were divided into two groups: those that showed a MINIMAL RECOVERY (A1-A2) and those that showed a rapid RECOVERY (A3-A4). Note that the reintroduction of bicuculline at the end of the experiment reduced the $\mathrm{Ca}^{2+}$ level in all neurons. $B$, The addition of the truncated NPY analog C2-NPY (100 nM) causcd a rapid and sustained $\mathrm{Ca}^{2+}$ depression. Unlike NPY, C2-NPY has very low nonspecific binding characteristics and therefore tends not to remain associated with cells. $C$, The NPY receptor antagonist benextramine $(10 \mu \mathrm{M})$ was added to the perfusion solution $3 \mathrm{~min}$ after NPY (100 nM) washout in an attempt to displace NPY that may have remained bound to the NPY receptor. Little effect was detected. $D$, NPY exhibited a latent regulation of GABAergic $\mathrm{Ca}^{2+}$ rises. The $\mathrm{Ca}^{2+}$ levels of the neurons shown in D1-D3 were elevated reversibly by the removal of bicuculline ( 20 $\mu \mathrm{M})$. During the third bicuculline application, neurons were pulsed with NPY (100 $\mathrm{nm}$ ) (vertical gray lines). Subsequent $\mathrm{Ca}^{2+}$ rises induced by the removal of bicuculline were reduced drastically. The arrow points to the 30 sec application of the glutamate receptor agonist $N M D A(30 \mu \mathrm{M}) . D 4$ is a graphical representation of the effect of NPY; 1st and 2nd refer to the two bicuculline-sensitive $\mathrm{Ca}^{2+}$ rises before the addition of NPY; $3 r d$ and $4 t h$ refer to the two bicuculline-sensilive $\mathrm{Ca}^{2+}$ rises after the pulse of NPY. The glutamate receptor antagonists AP5 (100 $\mu \mathrm{M})$ and $\mathrm{CNQX}(10 \mu \mathrm{M})$ were in all solutions except during NMDA application. Error bars represent SEM. 
been caused by residual NPY binding repeatedly to NPY receptors after bath washout, the putative NPY receptor antagonist benextramine was used. This antagonist has been reported to block $\mathrm{Y} 1$ and $\mathrm{Y} 2$ receptors, but it may not be fully effective at all NPY receptors (Li et al., 1991; Doughty et al., 1992; Penner et al., 1993; Palea et al., 1995). If residual NPY was binding repeatedly to NPY receptors, and thereby causing long-term calcium depression, the displacement of NPY with benextramine should cause a rapid $\mathrm{Ca}^{2+}$ elevation. The addition of benextramine $(10 \mu \mathrm{M}, 4 \mathrm{~min}$ application) 3 min after the withdrawal of NPY (100 nM) had no effect on the level of $\mathrm{Ca}^{2+}$ depression triggered by the addition of NPY (Fig. 2C). The level of depression during benextramine treatment (third min of application) was $77 \%$ (the $\mathrm{Ca}^{2+}$ rise before NPY application was $60 \pm 6 \mathrm{nM}$; the NPY-mediated $\mathrm{Ca}^{2+}$ decrease during benextramine application was $14 \pm 3 \mathrm{nM} ; n-20$ ). For neurons not treated with benextramine, the $\mathrm{Ca}^{2+}$ rise before NPY application was $55 \pm 7 \mathrm{~nm}$; NPY decreased the $\mathrm{Ca}^{2+}$ rise to $17 \pm 4 \mathrm{nM}$, representing a $69 \%$ drop in activity $(n=24)$. Data were collected over an identical time after NPY application for the two groups. These results provide additional evidence suggesting that the long-term effect of NPY is not attributable to NPY rebinding beyond the time it was perfused onto the neurons.

To understand the physiological events necessary for NPY to depress GABA-mediated $\mathrm{Ca}^{2+}$ increases, we tested the hypothesis that NPY would depress $\mathrm{Ca}^{2+}$ activity even if applied in the absence of a GABA-mediated $\mathrm{Ca}^{2+}$ rise. Figure 2D1-D3 shows that when NPY was applied and removed in the presence of bicuculline, it exerted no detectable effect on cytosolic $\mathrm{Ca}^{2+}$; however, the $\mathrm{Ca}^{2}$ increase after the removal of bicuculline was significantly lower than the $\mathrm{Ca}^{2+}$ increase before NPY application. This effect is shown in the neuron shown in Figure 2D2, where GABA-mediated $\mathrm{Ca}^{2+}$ increases are absent after NPY application. The bar graph in Figure $2 D 4$ quantifies the endogenous GABA-mediated $\mathrm{Ca}^{2+}$ rises before and after the addition of NPY. The second $\mathrm{Ca}^{2+}$ rise after the application of NPY was slightly higher than the first, suggesting that neurons were beginning to recover from NPY. This recovery is seen clearly in the neuron shown in Figure 2D1. These results demonstrate that the efficacy of NPY does not seem to be dependent on elevated cytosolic $\mathrm{Ca}^{2+}$.

\section{Mechanisms of NPY-induced $\mathrm{Ca}^{2+}$ depression}

The efficacy of several different NPY agonists was assayed in an attempt to identify the NPY receptor subtype responsible for the depression of GABA-mediated $\mathrm{Ca}^{2+}$ rises. Figure $3 A, B$ shows that both the Y2 receptor-specific agonist NPY 13-36 (100 nM) and the Y1 receptor-specific agonist $\left[\mathrm{Pro}^{34}, \mathrm{Leu}^{31}\right]$ NPY (100 nM) were effective at reducing $\mathrm{Ca}^{2+}$. Figure $3 C$ shows that the NPY receptor agonist PYY (100 nM) was also effective. In addition to these immediate effects, long- term $\mathrm{Ca}^{2+}$ depression could be induced by all three agonists.

We tested the hypothesis that NPY worked through a $\mathrm{G}$-protein-related mechanism to depress $\mathrm{Ca}^{2+}$ levels. Data were combined from three different coverslips. Figure $3 D$ shows that the response of SCN neurons to NPY was reduced drastically after treatment with the $G_{i} / G_{0}$ inhibitor pertussis toxin (200 $\mathrm{ng} / \mathrm{ml}$ ) for $20 \mathrm{hr}$ before the start of the experiment. After bicuculline removal, the $\mathrm{Ca}^{2+}$ level increased to $139 \pm 5 \mathrm{nM}$, a $68 \mathrm{nM}$ rise. The application of NPY reduced the $\mathrm{Ca}^{2+}$ rise to $54 \pm 4 \mathrm{nM}$, representing a $21 \% \mathrm{Ca}^{2+}$ decrease $(n=65)$. On the basis of normalized $\mathrm{Ca}^{2+}$ depressions, this depression is substantially ( $p$ $<0.01$, one-tailed $t$ test) smaller than NPY-mediated depression in the absence of pertussis toxin treatment described above (71\% decrease, $n=111)$. A bar graph representation comparing the short-term effects of NPY receptor agonists on GABA-mediated $\mathrm{Ca}^{2+}$ rises is shown in Figure $3 F$. The control rise represents the normalized GABA-mediated $\mathrm{Ca}^{2+}$ increase just before the application of NPY receptor agonists.

Next we tested whether NPY had an effect on $\mathrm{Ca}^{2+}$ during I -type voltage-activated $\mathrm{Ca}^{2+}$ channel inhibition. We showed previously that $\mathrm{Ca}^{2+}$ rises evoked by the application of GABA can be depressed $(86 \%)$ by nimodipine (Obrietan and van den Pol, 1995). Figure $3 E$ shows that endogenous GABAergic $\mathrm{Ca}^{2+}$ rises were depressed by the application of nimodipine $(1 \mu \mathrm{M})$ and that NPY $(100 \mathrm{nM})$ had little effect in the presence of nimodipine $(n=$ $19)$.

\section{Postsynaptic GABA-evoked $\mathrm{Ca}^{2+}$ rises}

Several NPY receptor agonists were used to determine whether the NPY receptor exerted a postsynaptic effect on GABA-evoked $\mathrm{Ca}^{2+}$ rises. Thirty second applications of GABA $(20 \mu \mathrm{M})$ were added repeatedly to the perfusion solution in either the absence or the presence of NPY receptor agonists $(100 \mathrm{nM})$. All perfusion solutions contained TTX $(1 \mu \mathrm{M})$ to inhibit neurotransmilter release and thereby eliminate effects that NPY may have on presynaptic GABA release from effects that NPY may have on postsynaptic responses to GABA. Figure $4 A$ shows that GABAevoked $\mathrm{Ca}^{2+}$ rises were depressed by the coadministration of NPY. The mean GABA-evoked $\mathrm{Ca}^{2+}$ rise in the absence of NPY was $115 \pm 7 \mathrm{nM}$. After NPY was added, the mean $\mathrm{Ca}^{2+}$ rise was $82 \pm 5 \mathrm{nM}$, representing a statistically significant $(p<0.001$, one-tailed $t$ test) $29 \%$ decrease ( $n=147$ from five experiments). Of 147 cells, $15 \%$ showed a NPY-mediated depression in GABAevoked $\mathrm{Ca}^{2+}$ rises. Half of the responding cells showed a depression that was characterized by an extended depression $(>50 \%)$ that persisted through the second application of GABA $(10 \mathrm{~min}$ post-NPY) (Fig. 4A, top neuron). The other half was characterized by a rapid recovery of GABA potency after NPY withdrawal (Fig. $4 A$, bottom neuron). The ability of NPY to depress GABA-evoked $\mathrm{Ca}^{3+}$ rises even after NPY withdrawal suggests there may be a postsynaptic component to the long-term $\mathrm{Ca}^{2+}$ depression characterized in experiments focusing on endogenous GABA-release assays.

Similar results were seen with $\mathrm{Y} 2$ and $\mathrm{Y} 1$ receptor-specific agonists (Fig. 4, $B$ and $C$, respectively) and PYY (Fig. 4D). NPY 13-36 (a Y2 agonist) was the most effective agonist, depressing GABA-evoked $\mathrm{Ca}^{2+}$ rises by $>48 \%(n=96)$. PYY induced a $\mathrm{Ca}^{2+}$ depression similar to NPY, depressing GABA-evoked $\mathrm{Ca}^{2+}$ by $>34 \%(n=38)$. High $(25 \mathrm{mM}) \mathrm{K}^{+}$-induced $\mathrm{Ca}^{2+}$ rises were also depressed by the coadministration of NPY (Fig. $4 E)(9 \%, n=$ 57). In the absence of NPY, the high $\mathrm{K}^{+}$-induced $\mathrm{Ca}^{2+}$ rise was $328 \pm 12 \mathrm{nM}$. After NPY was added, the mean $\mathrm{Ca}^{2+}$ rise decreased to $299 \pm 11 \mathrm{nM}$. The relative efficacy of NPY receptor agonists on evoked $\mathrm{Ca}^{2+}$ rises is shown in Figure 5; the first and second GABA application elevated $\mathrm{Ca}^{2+}$ to nearly equal levels, whereas all NPY receptor agonists significantly reduced the GABA-evoked $\mathrm{Ca}^{2+}$ rise ( $p<0.001$, one-tailed $t$ test). Separate experiments confirmed that GABA-induced $\mathrm{Ca}^{2+}$ rises were caused exclusively by activation of $\mathrm{GABA}_{\mathrm{A}}$ receptors; the $\mathrm{GABA}_{\mathrm{A}}$ receptor-specific agonist muscimol induced a $\mathrm{Ca}^{2+}$ rise, whereas the $\mathrm{GABA}_{B}$ agonist baclofen did not alter baseline $\mathrm{Ca}^{2+}$ levels (Fig. $4 F$ ). Similarly, GABA-induced $\mathrm{Ca}^{2+}$ increases were blocked completely by the $\mathrm{GABA}_{\mathrm{A}}$ receptor antagonist bicuculline $(20 \mu \mathrm{M})$ (Fig. 4G). 
A

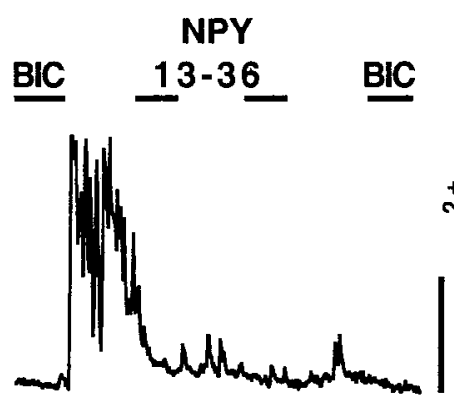

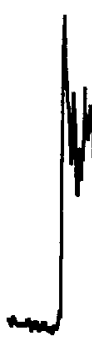

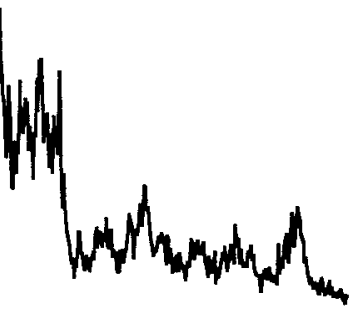

4 MIN
B

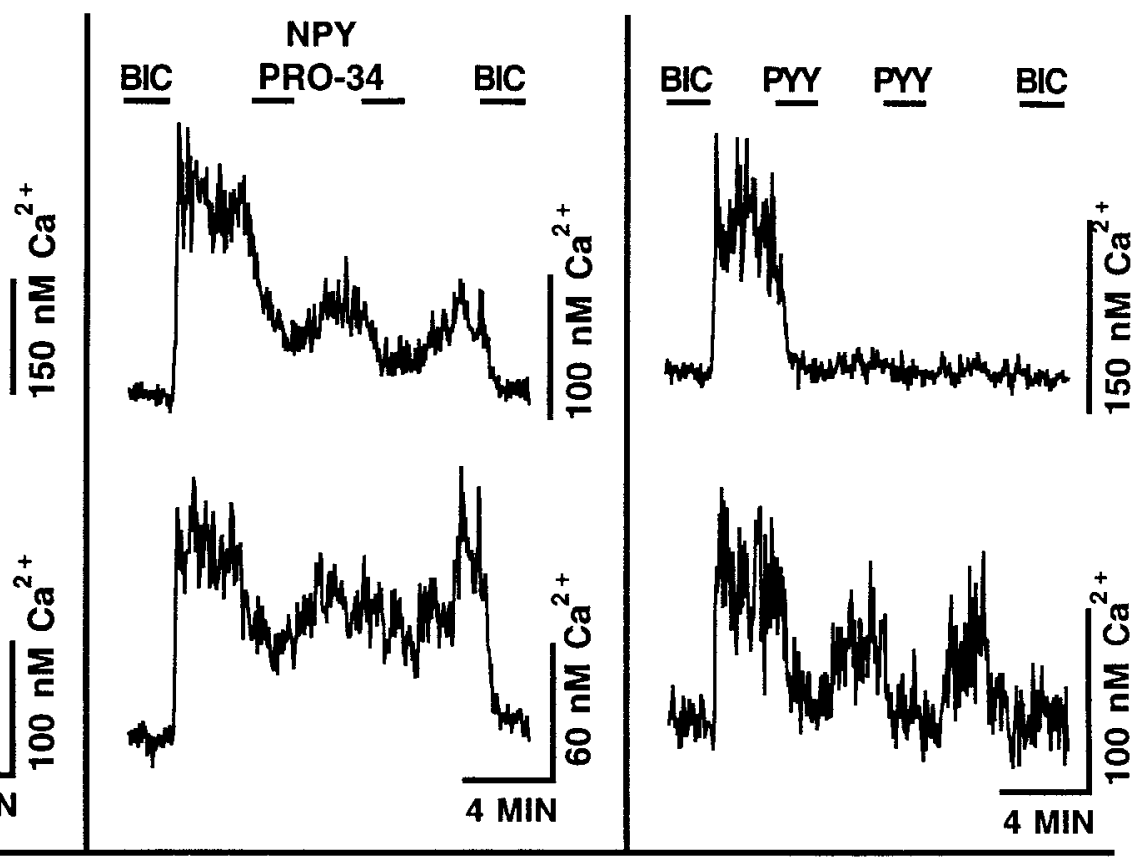

D. PERTUSSIS TOXIN PRETREATMENT

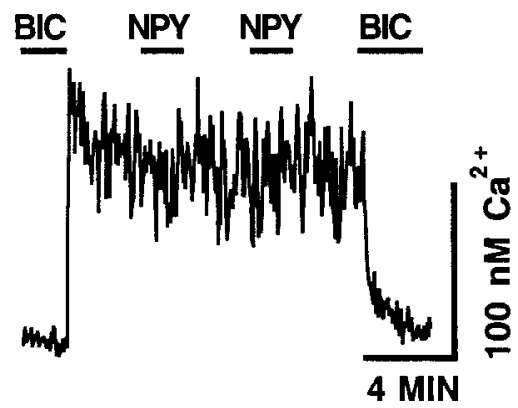

$\mathbf{E}$

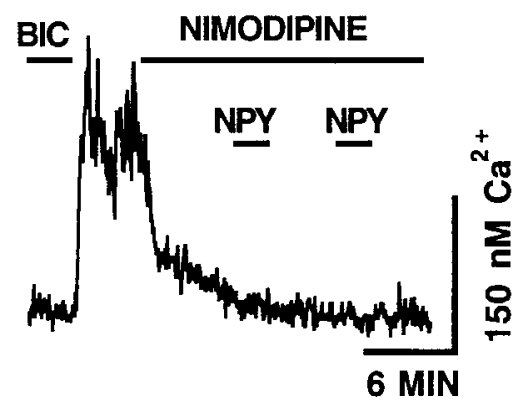

$\mathbf{F}$

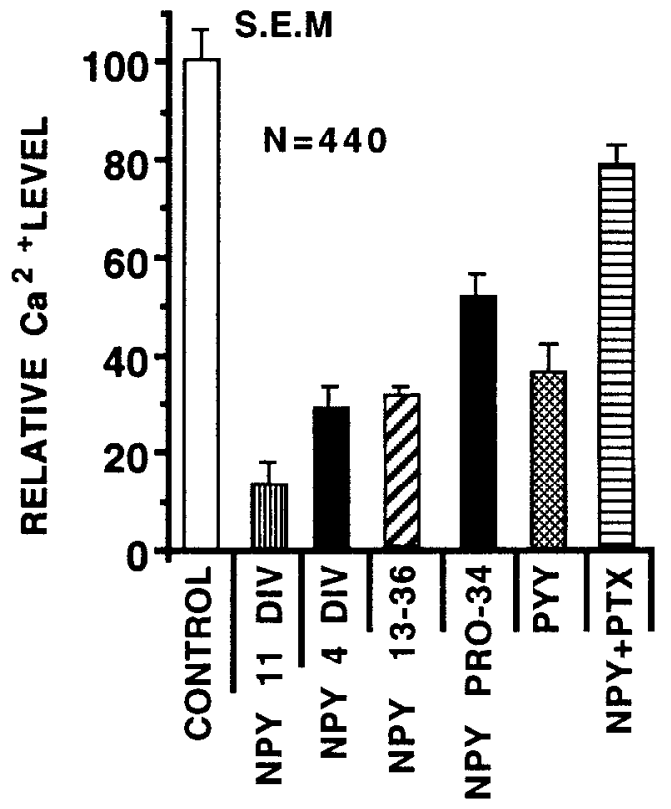

Figure 3. NPY receptor subtypes. A, The application of NPY (NPY 13-36) (100 nM) reduced GABA-mediated $\mathrm{Ca}^{2+}$ rises. Similar results were seen for $\left[\mathrm{Pro}^{34}, \mathrm{Leu}^{31}\right.$ ] NPY $(N P Y$ PRO-34) $(100 \mathrm{nM})(B)$, and $P Y Y(100 \mathrm{nM})(C)$. For each pair shown, the top neuron is an example of a long-term effect, and the bottom shows neurons that showed either a smaller effect $(A)$ or a more substantial recovery $(B, C) . D$, Pretreatment of SCN neurons with pertussis toxin $(200 \mathrm{ng} / \mathrm{ml})$ for $20 \mathrm{hr}$ before the start of the experiment blocked the NPY-mediated depression of GABAergic $\mathrm{Ca}^{2+}$ rises. $E$, GABAergic Ca ${ }^{2+}$ rises are in large part dependent on L-type $\mathrm{Ca}^{2+}$ channel activity. The response of a representative neuron shows that the addition of the $\mathrm{L}$-type $\mathrm{Ca}^{2+}$ channel blocker nimodipine $(1 \mu \mathrm{M})$ depressed the endogenous $\mathrm{Ca}^{2+}$ rise. NPY $(100 \mathrm{nM})$ had no effect in the presence of nimodipine. F, Bar graph representation of the efficacy of NPY receptor agonists. The $\mathrm{Ca}^{2+}$ rise defined from a bicuculline $(20 \mu \mathrm{M})$ baseline was determined $15 \mathrm{sec}$ before and 100 sec after the application of NPY receptor agonists. Values were normalized such that the $\mathrm{Ca}^{2+}$ rise just before the application of NPY (white bar) was set equal to $100 \%$. The agonists used are shown along the $x$-axis. The efficacy of NPY is shown for $11 D I V$ and $4 D I V$. NPY PRO-34 refers to [Pro ${ }^{34}$,Leu ${ }^{31}$ ] NPY. NPY $+P T X$ refers to the efficacy of NPY when the neurons were pretreated with pertussis toxin. The breakdown by group for the total number of neurons assayed $(n=440)$ was $4 D I V N P Y=111,11 D I V$ $N P Y=10, N P Y 13-36=81, N P Y P R O-34=98, P Y Y=75$, and $N P Y+P T X=65$. Only data from neurons with a $\mathrm{Ca}^{2+}$ rise $>20 \mathrm{nM}$ are included. Glutamate receptor antagonists AP5 $(100 \mu \mathrm{M})$ and CNQX $(10 \mu \mathrm{M})$ were in all solutions. NPY receptor agonist-mediated $\mathrm{Ca}^{2+}$ depression was statistically different from pre-NPY $\mathrm{Ca}^{2+}$ levels for each group $(p<0.001)$. BIC, Bicuculline. Error bars represent SEM. 


\section{GABA-EVOKED $\mathrm{Ca}^{2+}$ RISES DEPRESSED BY NPY RECEPTOR AGONISTS}

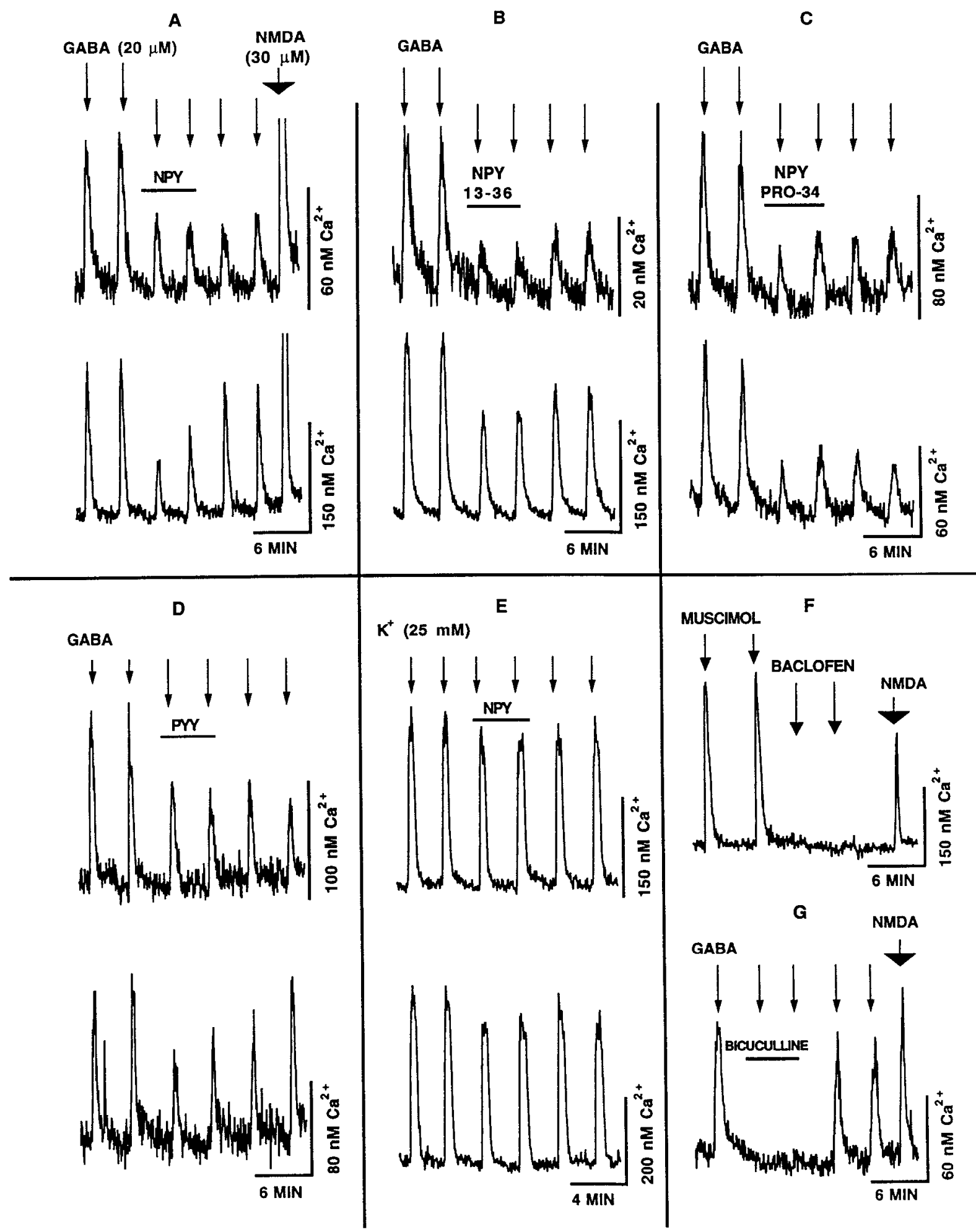

Figure 4. To determine whether NPY exerted a postsynaptic effect, synaptic communication was blocked with TTX (1 $\mu \mathrm{M})$, and GABA-induced Ca ${ }^{2+}$ rises were evoked repeatedly in combination with NPY receptor stimulation. $A$, The application of $G A B A(20 \mu \mathrm{M})($ arrows) to the perfusion solution elicited reproducible $\mathrm{Ca}^{2+}$ rises. The administration of $N P Y(100 \mathrm{nM})$ starting $45 \mathrm{sec}$ before GABA application caused a large reduction in the level of GABA-induced $\mathrm{Ca}^{2+}$ rises. NPY-dependent depression of GABA-induced $\mathrm{Ca}^{2+}$ increases either persisted (top neuron) or diminished (bottom neuron) after NPY was washed out. Cells were pulsed with NMDA $(30 \mu \mathrm{M})$ to demonstrate that neurons were healthy and would respond to Ca ${ }^{2+}$-mobilizing transmitters at the end of an experimental series (wide arrow). Similar results were seen for NPY 13-36 (B), [Pro ${ }^{34}$, Leu $\left.^{31}\right]$ NPY $(N P Y P R O-34)(C)$, and $P Y Y(D) . E$, The effect of NPY on high $\mathrm{K}^{+}$-induced $\mathrm{Ca}^{2+}$ rises was small. $F$, The $\mathrm{GABA}_{\mathrm{A}}$ receptor-specific agonist muscimol $(M U S C I M O L)(10 \mu \mathrm{M})$ elicited a $\mathrm{Ca}^{2+}$ rise, whereas the $\mathrm{GABA}_{\mathrm{B}}$ receptor-specific agonist baclofen $(B A C L O F E N)(10 \mu \mathrm{M})$ had no effect. $G, \mathrm{GABA}^{-e v o k e d ~ C a}{ }^{2+}$ rises could be inhibited by the coadministration of bicuculline (BICUCULLINE) $(20 \mu \mathrm{M})$. 


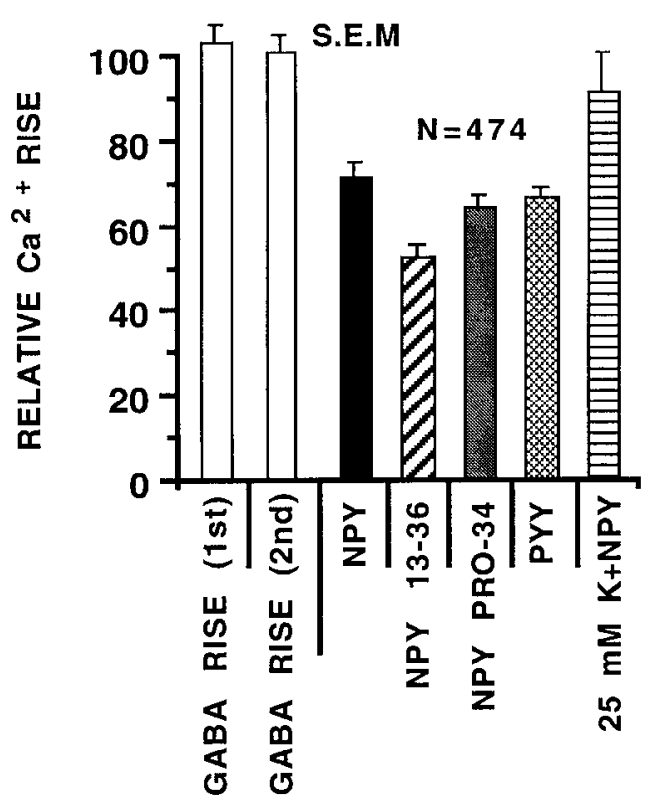

Figure 5. NPY receptor agonists suppressed GABA-evoked $\mathrm{Ca}^{2+}$ rises. Data compare sequential GABA-evoked $\mathrm{Ca}^{2+}$ rises. The graph shows that the peak response to the first control GABA-evoked $\mathrm{Ca}^{2+}$ rise was not different from the second control GABA-evoked $\mathrm{Ca}^{2+}$ rise (white bars). The second control GABA-evoked $\mathrm{Ca}^{2+}$ rise was normalized and set equal to $100 \%$ and then compared with the first $\mathrm{G} \wedge \mathrm{BA}$-evoked $\mathrm{Ca}^{2+}$ rise in the presence of NPY receptor agonist. All NPY receptor agonists caused a statistically significant depression in the peak $\mathrm{Ca}^{2+}$ rise $(p<$ $0.01)$. Data from high $\mathrm{K}^{+}$-induced $\mathrm{Ca}^{2+}$ increases $\left(25 \mathrm{~mm} \mathrm{~K}{ }^{+} N P Y\right.$ ) were analyzed in an identical manner to GABA-evoked responses. NPY $P R O-34$ refers to $\left[\mathrm{Pro}^{34}, \mathrm{Leu}^{31}\right]$ NPY. $N$ refers to the total number of neurons assayed. Error bars represent SEM. Only data from neurons with a $\mathrm{Ca}^{2+}$ rise $>20 \mathrm{nM}$ were analyzed.

\section{SCN microslices}

To simulate more closely in vivo conditions, the SCN was punched out of slices of neonatal rat brain and maintained as an organotypic mass. This minimizes the disruption of synaptic contacts and leaves the majority of neuronal processes intact. After $4 \mathrm{DIV}$, the ability of NPY to depress GABAergic $\mathrm{Ca}^{2+}$ rises was assayed (Fig. $6 A$ ). In the presence of bicuculline, the resting $\mathrm{Ca}^{2+}$ level was 69 $\pm 5 \mathrm{nM}$. After bicuculline was removed, the $\mathrm{Ca}^{2+}$ level increased to $111 \pm 3 \mathrm{nM}$, a $42 \mathrm{nM}$ rise. NPY reduced the $\mathrm{Ca}^{2+}$ rise to $13 \pm$ $4 \mathrm{nM}$, representing a statistically significant $(p<0.001$, one-tailed $t$ test) $69 \%$ drop in the GABA-mediated $\mathrm{Ca}^{2+}$ level $(n=14)$. As described earlier, the $\mathrm{Ca}^{2+}$-depressing-effect of NPY lasted long after NPY was removed from the perfusion solution.

Figure $6 B$ shows that the application of GABA $(20 \mu \mathrm{M})$ elicited a reproducible $\mathrm{Ca}^{2+}$ rise and that the peak level of the rise could be depressed by NPY (100 nM). The mean GABA-evoked $\mathrm{Ca}^{2+}$ rise in the absence of NPY was $113 \pm 13$ nм. After NPY was added, the mean $\mathrm{Ca}^{2+}$ rise was $79 \pm 6 \mathrm{nM}$, representing a statistically significant ( $p<0.001$, one-tailed $t$ test) $\mathrm{Ca}^{2+*}$ rise decrease of $30 \%(n=36)$. The efficacy of NPY at depressing GABAmediated $\mathrm{Ca}^{2+}$ rises in neurons from cultured microslices was similar to the results described for NPY using standard dissociation and culturing procedures.

\section{Arcuate nucleus}

To test the hypothesis that NPY depression of GABA-mediated $\mathrm{Ca}^{2+}$ rises found in SCN neurons are representative of a gencral mechanism of NPY action in the hypothalamus, we performed parallel experiments with neurons cultured from the hypothalamic arcuate nucleus. The arcuate nucleus is highly enriched in neurons that synthesize NPY and contains many neuroendocrine neurons that regulate pituitary hormone release. NPY exerts many cffects on the endocrine system, and some of these are long-lasting (Albers et al., 1990). This, in combination with the documented long-term regulatory role of NPY in pituitary function, makes the study of NPY-mediated modulation of GABAergic $\mathrm{Ca}^{2+}$ rises in the arcuate nucleus of keen interest. After $4 \mathrm{DIV}$, the efficacy of NPY was assayed. Figure $6 C$ shows that the GABA-induced $\mathrm{Ca}^{2+}$ rise in arcuate neurons was depressed by NPY (100 nM). The results from the arcuate nuclei are similar to those from the $\mathrm{SCN}$; NPY dramatically depressed GABA-mediated $\mathrm{Ca}^{2+}$ levels, and the effect persisted subsequent to the removal of NPY. The mean $\mathrm{Ca}^{2+}$ rise after the removal of bicuculline and just before the addition of NPY was $40 \pm 4 \mathrm{~nm}$. After NPY was added to the perfusion solution, the mean $\mathrm{Ca}^{2+}$ rise was depressed to $14 \pm 6$ $\mathrm{nM}$, representing a statistically significant $(p<0.001$, one-tailed $t$ test) $65 \%$ decrease $(n=19)$.

NPY was also effective in depressing postsynaptic GABAevoked $\mathrm{Ca}^{2+}$ rises (Fig. $6 D$ ). The mean GABA-evoked $\mathrm{Ca}^{2+}$ rise in the absence of NPY was $84+8 \mathrm{nM}$. The mean $\mathrm{Ca}^{2+}$ rise after the application of NPY was $47 \pm 5 \mathrm{nM}$, representing a statistically significant $\left(p<0.001\right.$, one-tailed $t$ test) $44 \%$ decrease in the $\mathrm{Ca}^{2+}$ $(n=35)$.

\section{DISCUSSION}

Ours is the first study examining transmitter modulation of GABA-mediated $\mathrm{Ca}^{2+}$ transients during development. Data presented show clearly that NPY receptor activation has a profound modulatory effect on SCN and arcuate ncural activity, capablc of depressing the endogenous GABA-mediated $\mathrm{Ca}^{2+}$ level and maintaining the level of depression long after the removal of NPY. The long-term depression appeared to be mediated through both presynaptic and postsynaptic mechanisms and could be generated with Y1 and Y2 NPY receptor-specific agonists and with PYY.

\section{Mechanisms}

The ability of NPY to depress GABA-evoked $\mathrm{Ca}^{2+}$ rises in the presence of TTX suggests that the NPY receptor can regulate neural activity postsynaptically. NPY-mediated postsynaptic modulation of neural activity has been shown under several different conditions. Shibata and Moore (1993) found that circadian firing rates of SCN neurons in slice preparations were modulated by NPY even in the presence of TTX, suggesting a postsynaptic site of action for NPY. A novel finding of our study was that both the $\mathrm{Y} 1$ and $\mathrm{Y} 2$ receptor-specific agonists depressed postsynaptic GABA-evoked $\mathrm{Ca}^{2+}$ rises. On the basis of the known pharmacological selectivity of the two receptor-specific agonists used (NPY 13-36 and $\left[\right.$ Pro $\left.^{34}, \mathrm{Leu}^{31}\right]$ NPY) (Fuhlendorff et al., 1990; Krstenansky et al., 1990), it is unlikely that the efficacy of the agonists was the result of agonist/receptor cross-reactivity. Rather, these results suggest that both receptor subtypes are expressed postsynaptically, modulating GABA-evoked $\mathrm{Ca}^{2+}$ rises. PYY was used to discriminate the Y1 and Y2 NPY receptors from the Y3 NPY receptor, which is not stimulated by PYY (Grundemar et al.; 1991; Wahlestedt et al., 1992). The efficacy of PYY closely matched the efficacy of NPY, suggesting that the Y3 type receptor did not contribute to NPY receptor agonist-elicited responses.

In other brain regions, NPY modulates $\mathrm{Ca}^{2+}$ channel currents (Hirning et al., 1990; Wiley et al., 1990, 1993; Klapstein and Colmers, 


\section{A. SCN EXPLANT}

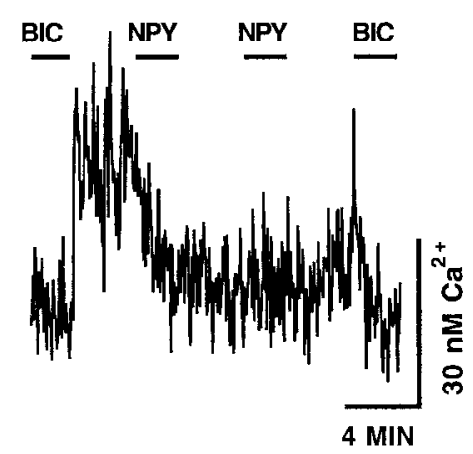

B. SCN EXPLANT

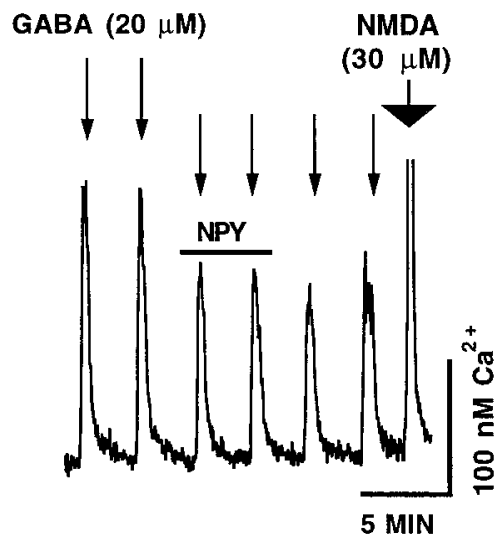

C. ARCUATE NEURON

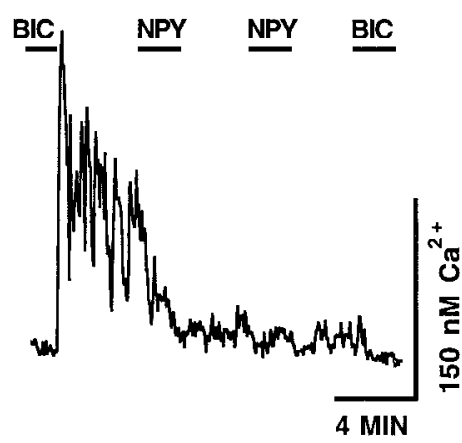

D. ARCUATE NEURON

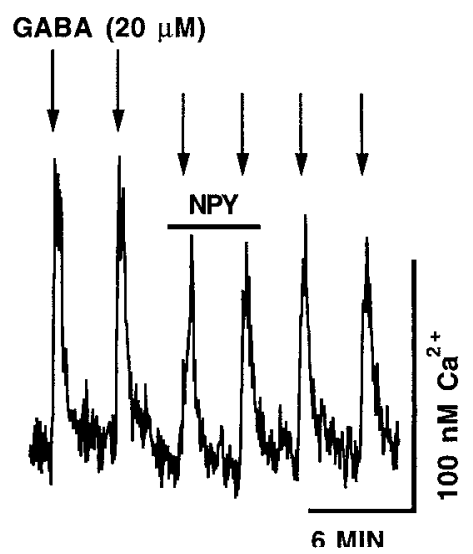

Figure 6. NPY (100 nM) depressed GABA-mediated $\mathrm{Ca}^{2+}$ rises in neurons from SCN cultured punches $(A$, $B)$ and in neurons cultured from the arcuate nucleus $(C, D) . A, C$, Removal of bicuculline $(B I C)(20 \mu \mathrm{M})$ clicitcd a $\mathrm{Ca}^{2+}$ risc that was depressed by the addition of $N P Y$. Glutamate receptor antagonists AP5 (100 $\mu \mathrm{M})$ and CNQX $(10 \mu \mathrm{M})$ were maintained in the perfusion solution during endogenous activity experiments. $B, D$, NPY depressed $\mathrm{Ca}^{2+}$ rises evoked by the application of GABA $(20 \mu \mathrm{M})$ to the perfusion solution. TTX $(1 \mu \mathrm{M})$ was included in all evokedresponse perfusion solutions in $B$ and $D$. adenosine $3^{\prime}, 5^{\prime}$-cyclic monophosphate or stimulating the synthesis of inositol trisphosphate (Perney and Miller, 1989; Bleakman et al., 1992; Herzog et al., 1992; Larhammar et al., 1992). We found that inhibiting $G_{i} / G_{o}$ protein activity with pertussis toxin dramatically reduced the NPY depression of spontaneous GABAergic $\mathrm{Ca}^{2+}$ rises. The ability of NPY to depress spontaneous glutamatergic $\mathrm{Ca}^{2+}$ rises in cortical ncurons also has becn shown to bc pertussis-toxin sensitive (Bleakman et al., 1992).

\section{Long-term $\mathrm{Ca}^{2+}$ depression}

A novel finding in the present study was that the $\mathrm{Ca}^{2+}$-depressing ability of NPY lasted well after NPY was washed away (>60 min). Long-term $\mathrm{Ca}^{2+}$ depression was particularly evident in experiments with neurons that were spontaneously releasing GABA from presynaptic axons, but it was also seen, although much less frequently, in experiments with GABA-evoked $\mathrm{Ca}^{2+}$ rises in SCN neurons. This depression may represent an underlying mechanism responsible for some of the extended phase-shifting effects of NPY if NPY modulates GABA in mature neurons as it does in developing ones, and by virtue of the retinal projection to NPY/ GABA-containing cells of the $1 \mathrm{GL}$ that project to the $\mathrm{SCN}$, it may also represent an underlying mechanism of light-induced phase shifts. Several studics have given hints of long-lasting effects of NPY on neural electrical activity (Shibata and Moore, 1988; Albers et al., 1990); however, data interpretation is difficult, as these experiments were performed in brain slices where the exchange of solutions is very slow. Because of the nonspecific binding characteristics of NPY, pharmacologically active concentrations of NPY could persist in thick slices for prolonged periods 
(hours) after the drug had been removed from the perfusion solution. This problem was eliminated in the present study by using synaptically coupled neurons in monolayer tissue culture where total washout of drugs should be achieved much more easily. Furthermore, we found long-term $\mathrm{Ca}^{2+}$ depression using the nonsticky NPY agonist C2-NPY, and we were not able to reduce the NPY-mediated long-term $\mathrm{Ca}^{2+}$ depression with the NPY receptor antagonist benextramine, suggesting that NPY receptor stimulation initiates second messenger pathways with effects that far outlast NPY application. Interestingly, although NPY depressed GABA-mediated $\mathrm{Ca}^{2+}$ rises in most neurons, the long-term effects were not found in all neurons examined. This may be attributable to different NPY or GABA receptors expressed in the cells and to different mechanisms of coupling to G-protein-regulated cascades of second messengers. Alternatively, if the SCN cells are undergoing circadian rhythms in vitro that are out of phase with each other (Bos and Mirmiran, 1990; Welsh et al., 1995), NPY may exert a long-term effect only at specific times of the cycle of the cells.

In addition to its long-term effects on circadian rhythms, NPY also exerts a long-lasting effect on stimulation of food intake and alters the timing of hormone secretion (McDonald et al., 1985, 1989; Stanley and Leibowitz, 1985; Albers et al., 1990). In the present study, we show that long-term NPY modulation of GABA activity is not restricted to the SCN, but is also found in neurons from other regions of the hypothalamus such as the neuroendocrine arcuate nucleus, suggesting that a common long-term effect of NPY receptor activation may be to depress GABA activity in hypothalamic neurons regulating various hypothalamic functions.

The effect of NPY on GABA-mediated $\mathrm{Ca}^{2+}$ is difficult to place within any specific model of long-term depression described previously (Linden and Connor, 1995). Both the magnitude and the frequency of the NPY effects were greater in experiments involving presynaptic release of GABA than in experiments with the addition of exogenous GABA, leading us to postulate that the effect of NPY in reducing $\mathrm{Ca}^{2+}$ levels of long periods of time may be attributable to reduction of synaptic efficacy of GABAergic axons. This would represent a form of long-term synaptic depression (LTD), although confirming electrophysiological evidence for this is still needed. NPY exerted a latent depression of GABAmediated $\mathrm{Ca}^{2+}$ rises. When NPY was applied and removed from the perfusion solution in the presence of bicuculline, subsequent GABA-mediated $\mathrm{Ca}^{2+}$ rises were depressed significantly or eliminated completely, thus suggesting that the long-term $\mathrm{Ca}^{2+}$. depressing ability of NPY was not dependent on postsynaptic depolarization and subsequent elevated $\mathrm{Ca}^{2+}$. This is contrary to some described forms of LTD, where increased $\mathrm{Ca}^{2+}$ levels were required for LTD induction (Wickens and Abraham, 1991; Christie and Abraham, 1992; Mulkey and Malenka, 1992). Activation of the ionotropic NMDA-selective glutamate receptor is thought to be involved in the initiation of LTD in many regions of the brain (Dudek and Bear, 1992; Jaffe et al., 1992). Although we found previously that NPY also can modulate glutamate actions in hypothalamic neurons (van den Pol et al., 1995), ionotropic glutamate receptor activity did not contribute to the extended depression of endogenous $\mathrm{GABAcrgic} \mathrm{Ca}^{2+}$ levels in our experiments; all endogenous activity assays were performed in the presence of glutamate receptor antagonists, thereby eliminating glutamate receptor responses and any effect endogenously released glutamate could have contributed to $\mathrm{Ca}^{2+}$ levels. It is possible that other transmitters were released simultaneously with GABA under conditions of spon- taneous release, but because GABA receptor antagonists completely blocked $\mathrm{Ca}^{2+}$ transients, GABA must be a critical transmitter mediating these effects.

\section{GABA and NPY during development}

GABA may be the principal $\mathrm{Ca}^{3+}$-elevating neurotransmitter during early development in the $\mathrm{SCN}$ and in other regions of the hypothalamus. An equimolar concentration of GABA elicits a higher $\mathrm{Ca}^{2+}$ rise than glutamate does in young, but not older, developing neurons (Obrietan and van den Pol, 1995). This is probably the result of the relatively early expression of the $\mathrm{GABA}_{\mathrm{A}}$ receptor in neural development, preceding glutamate receptor expression in many brain regions, including the hypothalamus (Meinecke and Rakic, 1992; Walton et al., 1993; Chen et al., 1995; van den Pol et al., 1995).

A physiological role for early developmental expression of GABA has been shown in the CNS. Hippocampal cells from 5- to 7-d-old rat pups can be depolarized by $\mathrm{GABA}_{\mathrm{A}}$ receptor agonists (Fiszman et al., 1990). Depolarizing potentials during the first week of postnatal development appeared to be the result of GABA release (Ben-Ari et al., 1989). Similarly, application of GABA in early embryogenesis elicited action potentials in the chick spinal cord that disappeared later in development (Obata et al., 1978). GABA-induced depolarization and subsequent $\mathrm{Ca}^{2+}$ entry would affect a myriad of developmentally regulated processes. $\mathrm{GABA}_{\mathrm{A}}$ receptor agonists also initiate chemokinesis in developmentally immature spinal cord neurons (Behar et al., 1994). $\mathrm{GABA}_{\mathrm{A}}$ receptor antagonists decrease neurite length of cultured hippocampal neurons (Barbin et al., 1993). More recently, LoTurco et al. (1995) found that DNA synthesis in cortical progenitor cells was decreascd by GABA.

Several studies have shown that similar to GABA and $\mathrm{GABA}_{\mathrm{A}}$ receptors, NPY and NPY receptors are present during the early stages of neurogenesis. In rat brain, NPY can be detected before E15 (Allen et al., 1984; Woodhams et al., 1985). High levels of NPY are found in neurons cultured from E18 hypothalamus (Wahle et al., 1993). Furthermore, NPY receptor mRNA has been found during embryogenesis in the developing brain (Larhammar et al., 1992; Janzin et al., 1993). Lateral geniculate nucleus neurons begin to extend NPY-containing processes toward the SCN during embryogenesis in hamster brain (Botchkina and Morin, 1995), a time when the developing SCN first starts to show circadian rhythmicity of 2 deoxyglucose uptake; this occurs at E19 in rats (Reppert, 1992).

The ability of NPY to depress (BABA-mediated $\mathrm{Ca}^{2+}$ rises and transients, and to do so for an extended period, would make NPY an agent capable of modulating many of the putative trophic effects GABA has been postulated to exert in the developing brain.

\section{REFERENCES}

Albcrs H, Fcrris C (1984) Neuropeptide Y: role in light-dark cycle entrainment of hamster circadian rhythms. Neurosci Lett 50:163-168.

Albers H, Ottenweller J, Liou S, Lumpkin M, Anderson E (1990) Neuropeptide $\mathrm{Y}$ in the hypothalamus: effect on corticosterone and singleunit activity. Am J Physiol 258:R376-R382.

Allen J, McGregor G, Woodhams P, Polak J, Bloom S (1984) Ontogeny of a novel peptide, neuropeptide $Y$ (NPY) in rat brain. Brain Res 303:197-200.

Bading H, Ginty D, Greenberg M (1993) Regulation of gene expression in hippocampal neurons by distinct calcium signaling pathways. Science 260:181-186.

Barbin G, Pollard H, Gaïarsa J, Ben-Ari Y (1993) Involvement of $\mathrm{GABA}_{\mathrm{A}}$ receptors in the outgrowth of cultured hippocampal neurons. Neurosci Lett 152:150-154. 
Barnea A, Hajibeigi A, Cho G, Magni P (1991) Regulated production and secretion of immunoreactive neuropeptide $\mathrm{Y}$ by aggregating fetal brain cells in cultures. Neuroendocrinology 54:7-13.

Behar T, Schaffner A, Colton C, Somogyi R, Olah Z, Lehel C, Barker J (1994) GABA-induced chemokinesis and NGF-induced chemotaxis of embryonic spinal cord neurons. J Neurosci 14:29-38.

Ben-Ari Y, Cherubini E, Corradetti R, Gaïarsa J (1989) Giant synaptic potentials in immature rat CA3 hippocampal neurones. J Physiol (Lond) 416:303-325.

Bleakman D, Harrison N, Colmers W, Miller R (1992) Investigation into neuropeptide $Y$-mediated presynaptic inhibition in cultured hippocampal neurones of the rat. Br J Pharmacol 107:334-340.

Bos NPA, Mirmiran M (1990) Circadian rhythms in spontaneous neuronal discharges of the cultured suprachiasmatic nucleus. Brain Res 511:158-162.

Botchkina G, Morin L (1995) Specialized neuronal and glial contributions to development of the hamster lateral geniculate complex and circadian visual system. J Neurosci 15:190-201.

Card J, Moore R (1984) The suprachiasmatic nucleus of the golden hamster: immunohistochemical analysis of cell and fiber distribution. Ncuroscience 13:415-431.

Card J, Moore R (1989) Organization of lateral geniculate-hypothalamic connections in the rat. 284:135-147.

Chen G, Trombley PQ, van den Pol AN (1995) GABA receptors precede glutamate receptors in hypothalamic development; differential regulation by astrocytes. J Neurophysiol 74:1473-1484.

Chen G, Trombley PQ, van den Pol AN (1996) Excitatory actions of GABA in developing hypothalamus. J Physiol (Lond), in press.

Christie B, Ahraham W (1992) NMDA-dependent heterosynaptic longterm depression in the dentate gyrus of anesthetized rats. Synapse $10: 1-6$.

Chronwall B, DiMaggio D, Massari V, Pickel V, Ruggiero D, O'Donohuc $T$ (1985) The anatomy of neuropeptide $Y$ containing neurons in the rat brain. Neuroscience 15:1159-1181.

Colmers W, Lukowiak K, Pittman Q (1988) Neuropeptide Y action in the rat hippocampal slice: site and mechanism of presynaptic inhibition. J Neurosci 8:3827-3837.

Decavel C, van den Pol A (1990) GABA: a dominant transmitter in the hypothalamus. J Comp Neurol 302:1019-1037.

Doughty M, Li K, Hu L, Chu S, Tessel R (1992) Benextramineneuropeptide $Y$ (NPY) binding site interactions: characterization of tritiated-NPY binding site heterogeneity in rat brain. Neuropeptides 23:169-180.

Dudek S, Bear M (1992) Homosynaptic long-term depression in area CA1 of hippocampus and effects of $N$-methyl-D-aspartate receptor blockade. Proc Natl Acad Sci USA 89:4363-4367.

Fiszman M, Novotny E, Lange G, Barker J (1990) Embryonic and early postnatal hippocampal cells respond to nanomolar concentrations of muscimol. Dev Brain Res 53:186-193.

Forscher P, Kaczmarek L, Buchanan J, Smith S (1987) Cyclic AMP induces changes in distribution and transport of organelles within growth cones of Aplysia bag cell neurons. J Neurosci 7:3600-3611.

Fuhlendorff J, Gether U, Aakerlund L, Langeland-Johansen N, Thogersen H, Melberg S, Olsen U, Thastrup O, Schwartz T (1990) $\left[\mathrm{Leu}^{31}\right.$, Pro $\left.^{34}\right]$ neuropeptide $\mathrm{Y}$ : a specific Y1 receptor agonist. Proc Natl Acad Sci USA 87:182-186.

Greber S, Schwarzer C, Sperk G (1994) Neuropeptide Y inllibits potassium-stimulated glutamate release through $\mathrm{Y} 2$ receptors in rat hippocampal slices in vitro. Br J Pharmacol 113:737-740.

Grundemar L, Wahlestedt C, Reis D (1991) Neuropeptide Y acts at an atypical receptor to evoke cardiovascular depression and to inhibit glutamate responsiveness in the brainstem. J Pharmacol Exp Ther 258:633-638.

Grynkiewicz G, Poenie M, Tsien R (1985) A new generation of calcium indicators with greatly improved fluorescence properties. J Biol Chem 260:3440 -3450 .

Hansen G, Belhage B, Schousboe A, Meier E (1987) Temporal development of GABA agonist induced alterations in ultrastructure and GABA receptor expression in cultured cerebellar granule cells. Int $\mathbf{J}$ Dev Neurosci 5:263-269.

Harrington ME, Rusak B (1986) Lesions of the thalamic intergeniculate leaflet alter hamster circadian rhythms. J Biol Rhythms 1:309-325.

Harrington ME, Nance DM, Rusak B (1985) Neuropeptide Y immunoreactivity in the hamster geniculo-suprachiasmatic tract. Brain Res Bull $15: 465-472$.
Herzog H, Hort Y, Ball H, Hayes G, Shine J, Selbie L (1992) Cloned human neuropeptide $Y$ receptor couples to two different second messenger systems. Proc Natl Acad Sci USA 89:5794-5798.

Hirning L, Fox A, Miller R (1990) Inhibition of calcium currents in cultured rat myenteric neurons by neuropeptide $\mathrm{Y}$ : evidence for direct receptor/channel coupling. Brain Res 532:120-130.

Horvath G, Acs Z, Mergl Z, Nagy I, Makara G (1993) $\gamma$ Aminobutyric acid-induced elevations of intracellular calcium concentrations in pituitary cells of neonatal rats. Neuroendocrinology 57:1028-1034.

Hulıman K, Albers H (1994) Neuropeptide Y microinjected into the suprachiasmatic region phase shifts circadian rhythms in constant darkness. Peptides 8:1475-1478.

Huhman K, Babagbemi T, Albers H (1995) Bicuculline blocks neuropeptide $\mathrm{Y}$-induced phase advances when microinjected in the suprachiasmatic nucleus of syrian hamsters. Brain Res 675:333-336.

Jaffe D, Johnston D, Lasser-Ross N, Lisman J, Miyakawa H, Ross W (1992) The spread of Na spikes determines the pattern of dendritic $\mathrm{Ca}$ entry into hippocampal neurons. Nature 357:244-246.

Janzin E, Zhang X, Söderstrom S, Williams R, Hökfelt T, Ebendal T, Larhammar D (1993) Expression of peptide YY and mRNA for the NPY/PYY receptor of the Y1 subtype in dorsal root ganglia during rat embyrogenesis. Dev Brain Res 76:105-113.

Johnson RF, Moore RY, Morin LP (1989) Lateral geniculate lesions alter circadian activity rhythms in the hamster. Brain Res Bull 22:411-422.

Jolicoeur F, Bouali S, Fournier A, St-Pierre S (1995) Mapping of hypothalamic sites involved in the effects of NPY on body temperature and food intake. Brain Res Bull 36:125-129.

Khanna S, Sibbald J, Day T (1993) Neuropeptide Y modulation of A1 noradrenergic neuron input to supraoptic vasopressin cells. Neurosci Lett 161:60-64.

Klapstcin G, Colmers F (1992) 4-Aminopyridine and low $\mathrm{Ca}^{2+}$ differentiate presynaptic inhibition mediated by neuropeptide $\mathrm{Y}$, baclofen and 2-chloroadenosine in rat hippocampal CA1 in vitro. Br J Pharmacol $105: 470-474$

Krstenansky J, Owen T, Payne M, Shatzer S, Buck S (1990) C-terminal modifications of neuropeptide $\mathrm{Y}$ and its analogs leading to selectivity for the mouse brain receptor over the porcine spleen receptor. Neuropeptides 17:117-120.

Larhammar D, Blomqvist A, Yee F, Jazin F, Yoo H, Wahlested C. (1992) Cloning and functional expression of a human neuropeptide $\mathrm{Y} /$ peptide YY receptor of the Y1 type. J Biol Chem 267:10935-10938.

Li W, Macdonald R, Hexum T (1991) Benextramine irreversibly inhibits iodine-125 neuropeptide $\mathrm{Y}$ affinity labeling of the $\mathrm{Y} 2$ binding protein in bovine hippocampus. Eur J Pharmacol 5:89-91.

Linden D, Connor J (1995) Long-term synaptic depression. Annu Rev Neurosci 18:319-357.

LoTurco J, Owens D, Heath M, Davis M, Kriegstein A (1995) GABA and glutamate depolarize cortical progenitor cells and inhibit DNA synthesis. Neuron 15:1287-1298.

Martire M, Pistritto G, Mores N, Agnati L, Fuxe K (1993) Regionspecific inhibition of potassium-evoked $\left[{ }^{3} \mathrm{H}\right]$ noradrenaline release from rat brain synaptosomes by neuropeptide $\mathrm{Y}-(13-36)$ : involvement of NPY receptors of the Y2 type. Eur J Pharmacol 230:231 234.

Mattson MP, Kater SB (1987) Calcium regulation of neurite elongation and growth cone motility. J Neurosci 7:4034-4043.

McDonald JK, Lumpkin MD, DePaolo LV (1989) Neuropeptide-Y suppresses pulsatile secretion of luteinizing hormone in ovariectomized rats: possible site of action. Endocrinology 125:186-191.

McDonald JK, Lumpkin MD, Samson WK, McCann SM (1985) Neuropeptide $\mathrm{Y}$ affects secretion of luteinizing hormone and growth hormone in ovariectomized rats. Proc Natl Acad Sci USA 82:561-564.

McLean R, Buck S, Krstenansky J (1990) Examination of the role of the amphipathic alpha-helix in the interaction of neuropeptide $\mathrm{Y}$ and active cyclic analogues with cell membrane receptors and dimyristoylphosphatidylcholine. Biochemistry 29:2016-2022.

McQuiston A, Petrozzoni J, Conner J, Colmers W (1996) Neuropeptide $\mathrm{Y} 1$ receptors inhibit $\mathrm{N}$-type calcium currents and reduce transient calcium increases in rat dentate granule cells. J Neurosci 16:1422-1429.

Medanic M, Gillette M (1993) Suprachiasmatic circadian pacemaker of rat shows two windows of sensitivity to neuropeptide $\mathrm{Y}$ in vitro. Brain Res 620:281-286.

Meier E, Drejer J, Schousboe A (1984) GABA induces functionally active low-affinity GABA receptors on cultured cerebellar granule cells. J Neurochem 43:1737-1744. 
Meınecke D, Rakıc P (1992) Expression of GABA and GABA receptors by neurons of the subplate zone in developing primate occipital cortex evidence for transient local circuits J Comp Neurol 317 91-101

Michler A (1990) Involvement of GABA receptors in the regulation of neurite growth in cultured embryonic chick tectum Int J Dev Neurosci $8463-472$

Moore R, Speh J (1993) GABA is the principal neurotransmitter of the crrcadian system Neurosa Lett 150 112-116

Morely J, Flood J (1990) Neuropeptıde Y and memory processıng Ann NY Acad Sci $611226-231$

Mulkey R, Malenka R (1992) Mechanısms underlyıng inductıon of homosynaptic long-term depression in area CA1 of the hippocampus Neuron 9 967-975

Obata K, Oide M, Tanaka H (1978) Excitatory and inhibitory actıons of GABA and glycine on embryonıc chick spinal neurons in culture Brain Res $144179-184$

Obrietan K, van den Pol A (1995) GABA neurotransmission in the hypothalamus developmental reversal from $\mathrm{Ca}^{2+}$ elevatıng to depressIng J Neurosci 15 5065-5077

Palea S, Cors1 M, Rımland J, Trist D (1995) Discrımınatıon by benextramine between the NPY-Y-1 receptor subtypes present in rabbit isolated vas deferens and saphenous vem $\mathrm{Br}$ J Pharmacol 115 3-10

Penner S, Smyth D, Glavin G (1993) Effects of neuropeptıde Y and $\left[\mathrm{Leu}^{31}, \mathrm{Pro}^{34}\right]$ neuropeptide $\mathrm{Y}$ on experimental gastric lesion formation and gastric secretion in the rat $J$ Pharmacol Exp 'Ther 266 339-343

Perney T, Miller R (1989) Two different G-proteins mediate neuropeptıde $\mathrm{Y}$ and bradykının-stımulated phospholıpıd breakdown in cultured rat sensory neurons J Biol Chem 264 7317-7327

Reppert S (1992) Pre-natal development of a hypothalamıc bıological clock Prog Brain Res 93 119-131

Rusak B, Meijer JH, Harrington ME (1989) Hamster circadian rhythms are phase-shifted by electrical stımulation of the geniculo-hypothalamic tract Brain Res 498 283-291

Shibata S, Moore R (1988) Neuropeptide Y and vasopressin effects on rat suprachısmatic nucleus neurons in vitro J Biol Rhythms $3265-276$

Shibata S, Moore R (1993) Neuropeptide Y and optic chiasm stımulation affect suprachidsmatic nucleus circadian function in vitro Brain Res 615 95-100

Simonneaux V, Ouichou A, Craft C, Pevet P (1994) Presynaptic and postsynaptic effects of neuropeptide $\mathrm{Y}$ in the rat pineal gland $\mathrm{J}$ Neurochem $622464-2471$

Spoerr1 P (1988) Neurotrophic effects of GABA in cultures of embyronic chick brain and retına Synapse 2 11-22

Stanley B, Leıbowitz S (1985) Neuropeptide Y injected in the paraventricular hypothalamus a powerful stımulant of feedıng behavior Proc Natl Acad Sc1 USA 82 3940-3943

Swanson L, Cowan W, Jones E (1974) An dutoradiographic study of the efferent connections of the ventral lateral geniculate nucleus in the albino rat and cat $\mathbf{J}$ Comp Neurol 156 143-163

Vaccarno F, Haywark M, Nestler E, Duman R, Tallman J (1992) Differential induction of immediate early genes by excitatory amıno acid receptor types in primary cultures of cortical and striatal neurons Mol Brain Res 12 233-241

van den Pol AN, Dudek FE (1993) Cellular communication in the circadian clock, the suprachiasmatic nucleus Neuroscience 56 793-811 van den Pol AN, Gores T (1986) Synaptic relationships between neurons containıng vasopressin, GRP, VIP, and glutamate decarboxylase immunoreactivity in the the suprachiasmatic nucleus dual ultrastructural immunocytochemistry with gold substituted silver peroxidase J Comp Ncurol 252 507-521

van den Pol AN, Tsujimoto K (1985) Neurotransmitters of the hypothalamic suprachiasmatic nucleus immunocytochemical analysis of $25 \mathrm{neu}-$ ronal antigens Neuroscience 15 1049-1086

van den Pol AN, Obrietan K, Cao V, Trombley PQ (1995) Embryonic hypothalamic expression of functional glutamate receptors Neuroscience $67419-439$

van den Pol AN, Obrietan K, Belousov A (1995) NPY modulation of hypothalamic glutamate transmıssion Soc Neurosci $\Lambda$ bstr 22430

Wahle P, Muller T, Swandulla D (1993) Characterization of neurochemical phenotypes in cultured hypothalamic neurons with immunohistochemistry and in situ hybridization Brain Res $61137-45$

Wahlestedt C, Regunathan S, Reis D (1992) Identification of cultured cells selectively expressing Y1-, Y2-, or Y3-type receptors for neuropeptide Y/peptide YY Life Sc1 50 PL7-12

Walker M, Ewald D, Perney T, Miller R (1988) Neuropeptide Y modulates neurotransmitter release and $\mathrm{Ca}^{2+}$ currents in rat sensory neurons J Neurosci $82438-2446$

Walton M, Schaffner A, Barker J (1993) Sodium channels, GABA receptors, and glutamate receptors develop sequentially on embryonic rat spinal cord cells J Neuroscr 13 2068-2084

Welsh DK, Logothetis DE, Meister M, Reppert SM (1995) Individudl neurons dissociated from rat suprachiasmatic nucleus express independently phased circadian firıng rhythms Neuron 14 697-706

Westfall T, Carpentier S, Chen X, Beinfeld M, Naes L, Meldrum M (1987) Prejunctional and postjunctional effects of neuropeptide $Y$ at the noradrenergic neuroeffector junction of the perfused mesenteric arterial bed of the rat J Cardiovasc Pharmacol 10 716-722

Wickens J, Abraham W (1991) The involvement of L-type calcium channels in heterosynaptıc long-term depression in the hıppocampus Neuroscı Lett $130128-132$

Wiley J, Gross R, Lu Y, Macdonald R (1990) Neuropeptıde Y reduces calcium current and inhibits acetylcholine release in nodose neurons via a pertussis toxin-sensitive mechanism J Neurophysiol 63 1499-1507

Wiley J, Gross R, Macdonald R (1993) Agonists for neuropeptide Y receptor subtypes NPY-1 and NPY-2 have opposite actions on rat nodose neuron calcium currents J Neurophysiol 70 324-330

Woodhams P, Allen Y, McGovern J, Allen J, Bloom S, Balazs R, Polak J (1985) Immunohistochemical analysis of the early ontogeny of the neuropeptide $Y$ system in rat brain Neuroscience 15 173-202

Yamashita M, Fukuda Y (1993) Calcium channels and GABA receptors in the early embryonic chick retına J Neurobılol 24 1600-1614

Yokoo H, Schlesinger D, Goldstein M (1987) The effect of neuropeptide $\mathrm{Y}$ (NPY) on stımulation-cvoked relcase of $\left[{ }^{3} \mathrm{H}\right]$ norcpinephrinc (NE) from rat hypothalamic and cerebral cortical slices Eur J Pharmacol $143283-286$

Yuste R, Katz L (1991) Control of postsynaptıc $\mathrm{Ca}^{2+}$ influx in developing neocortex by excitatory and inhibitory neurotransmitters Neuron $6333-344$ 